\title{
LOCAL HUMANITARIAN LEADERSHIP AND RELIGIOUS LITERACY Engaging with Religion, Faith, and Faith Actors
}

\section{TARA R. GINGERICH, DIANE L. MOORE, ROBERT BRODRICK, AND CARLEIGH BERIONT}

Local humanitarian leadership is built upon the premise that humanitarian action should be led by local humanitarian actors whenever possible, yet this research finds that secular humanitarian INGOs do not engage systematically with local faith actors in their local leadership work. Based primarily on interviews with humanitarian INGO staff, this research also found that neither secular nor faith-inspired international humanitarian organizations have a sufficient level of religious literacy to enable them to understand the religious dimensions of the contexts in which they work and to effectively navigate their engagement with local faith actors.

With assistance from the Henry Luce Foundation 


\section{CONTENTS}

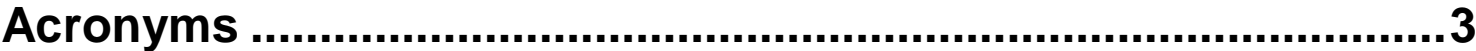

Executive Summary .....................................................................

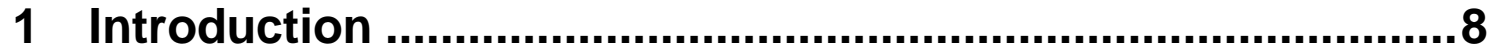

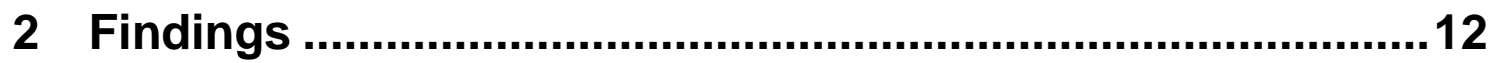

3 Analysis and Recommendations........................................22

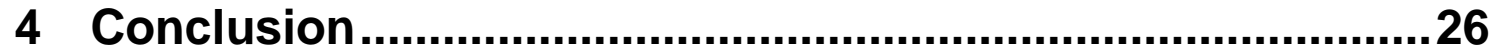

Appendix: Interviews and Consultations .................................27

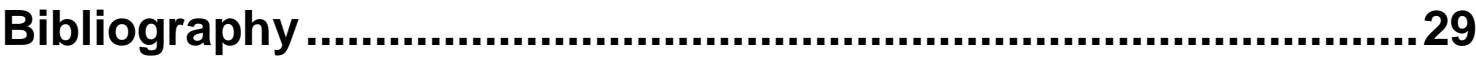

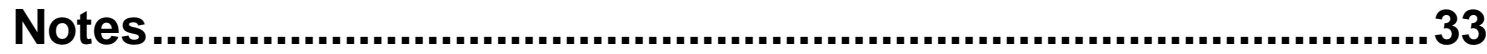

Acknowledgments ..................................................................... 41 


\section{ACRONYMS}

ADRA

CAFOD

CBO

CRS

DRR

FBO

$\mathrm{FIO}$

GBV

INGO

IR

JLI

LFA

LGBTQ

LHL

LNHA

MEAL

NGO

PAR

PaRD

UN

UNHCR

VAW

WASH
Adventist Development and Relief Agency

Catholic Agency For Overseas Development

Community-based organization

Catholic Relief Services

Disaster risk reduction

Faith-based organization

Faith-inspired organization

Gender-based violence

International non-governmental organization

Islamic Relief

Joint Learning Initiative on Faith \& Local Communities

Local faith actor

Lesbian, gay, bisexual, transgender, and queer

Local humanitarian leadership

Local and national humanitarian actor

Monitoring, evaluation, and learning

Non-governmental organization

Participatory action research

Partnership for Religion and Development

United Nations

UN High Commissioner for Refugees

Violence against women

Water, sanitation, and hygiene 


\section{EXECUTIVE SUMMARY}

Local humanitarian leadership (LHL) is the talk of the humanitarian field these days. This is the idea that it should be governments and civil societies in crisis-affected countries that are leading the humanitarian assistance in their countries, whenever possible, supported by the international community. LHL has recently gained some traction, even by some of the international actors who would need to cede power and resources to bring about such a change. Of course, local leadership is happening all the time, around the world, primarily in disaster risk reduction (DRR), disaster preparedness, and in response to small- and mediumsized "natural disasters" 1 and conflicts. Yet the work that lies ahead to bring about a transformational change-a complete revamping of the system that has been in place for the past 60 years-cannot be underestimated. Change will need to occur at every level, by every actor.

In the context of local humanitarian leadership, one of the areas that requires critical attention is religion and faith actors, and that is the subject of this scoping research. Despite its powerful relevance in humanitarian crises and responses-and for the move toward local humanitarian leadership-religion has been considered the "third rail" of humanitarian assistance: ${ }^{2}$ so controversial and charged that it should be avoided.

First, religion and faith themselves play an enormous role in crises, as both real and purported causes of conflicts at the communal, state, regional, and even global level. Humanitarian and political actors are forced to contend with these issues in their everyday work, yet many tend to be oblivious to the positive role that religious factors can play in the outcome of a crisis. Negative impacts of religion (e.g., violent extremism, human rights abuses) are more readily apparent and are often generalized, in the sense that religion is portrayed as a dangerous and problematic force. As a result, humanitarian and political actors are left with the choice to either buy into this portrayal or temper its impact by considering religion a relatively benign but essentially inconsequential cultural feature. In this way, the power of religion is too often simplistically associated with negative consequences that, even when true, fail to account for the greater complexity of the underlying causes that give rise to extremist representations. A more nuanced and sophisticated understanding of the complex roles that religions and religious institutions play in local contexts would help international actors work with local populations to mitigate the negative impacts of religious expression and strengthen the positive forces.

Second, religion and faith enter the humanitarian sphere as people affected by crises stemming from natural hazards and conflict struggle to make sense of, come to terms with, and recover from trauma and loss. This aspect of humanitarian action tends to be supported by faith-inspired humanitarian actors but largely avoided by other actors for many reasons, including a belief that religion is a personal rather than public matter and one that must be avoided in order to maintain their secularity (which is associated with impartiality in the minds of many). ${ }^{3}$ (For definitions of faith-inspired NGOs, secular NGOs, and other terms, see page 11) One of the main sources of unease on the part of secular international humanitarian actors in their engagement with local faith actors-and their support of them as partners and local humanitarian leaders-is local faith actors' (LFAs') provision of spiritual assistance and concerns around impartiality and proselytism. This research looks in greater depth at both the engagement and the concerns.

A third way that religion comes into play in humanitarian action is through faith-inspired humanitarian actors. There are faith-inspired humanitarian international non-governmental organizations (INGOs) that operate in the global humanitarian system alongside their secular counterparts, but do so with a basis in a religious tradition. Building on existing research examining religion and humanitarian assistance, ${ }^{4}$ this research found little difference in the strategies and practices that these organizations employ in their local humanitarian leadership work, except around the local actors with which they partner. International faith-inspired organizations (FIOs) tend to work in networks of local faith actors, and it is primarily LFAs with whom they partner, support, and promote as local humanitarian leaders, whereas secular humanitarian international NGOs tend to partner with secular local actors and engage with LFAs on an ad hoc basis and not in their local humanitarian leadership work. One role that mediumsized FIOs do appear to play more than their secular counterparts is that of an intermediary between larger INGOs and local faith actors. 
Local faith actors are the other actors we consider in the intersection of local humanitarian leadership and religion. One critical change in the move toward LHL becoming the organizing principle of humanitarian assistance is that international actors-donors, multilateral agencies, and INGOs - need to more fully recognize, acknowledge, and respect the capabilities, needs, priorities, and culture of local humanitarian actors. Taking local actors seriously means seeing them for who they are and who they want to be, with beliefs and practices that may be very different from those of humanitarian workers from the global North.

Nowhere is this more challenging than with local faith actors. There are thousands of LFAs, ranging from religious institutions (churches, mosques, temples, etc.) and networks of religious institutions to faith-inspired community-based organizations (CBOs) to faith-inspired nongovernmental organizations (NGOs). The approach of LFAs to humanitarian assistance varies widely, as does the engagement by international humanitarian actors with them. On the one hand, many believe that as local actors who 1) are first responders and have been providing humanitarian assistance and acting as social safety nets in their communities for decades, if not centuries; 2) have great logistical access; 3) are respected in their communities; and 4) have the ability to affect social change (e.g., on gender equality, violence against women, early marriage) in their communities, LFAs should be among the local actors with which INGOs are considering partnering and supporting in their work toward local humanitarian leadership.

On the other hand, there are concerns and risks related to local faith actors, including that they 1 ) do not always adequately represent their entire communities, particularly the most vulnerable, and the people put forth as leaders often represent the traditional hierarchies; 2) do not consistently embody and promote gender and lesbian, gay, bisexual, transgender, and queer (LGBTQ) equality; 3) do not consistently meet technical standards; 4) are not always able to scale up in times of crisis; and 5) do not always subscribe or adhere to the humanitarian principles (for a detailed discussion of these principles, see page 16). Conversations about local actors and the humanitarian principles are complicated in general by questions about the continuing relevance of the principles and equal expectations of adherence by both local and international actors. But they are further complicated when considering delivery of humanitarian assistance by LFAs. Our research found a pervasive stigma regarding non-adherence to the humanitarian principle of impartiality by LFAs as well as evidence of actual problems with partiality and proselytizing that need to be addressed, both of which result in obstacles to the provision of aid to those most in need.

Secular and faith-inspired humanitarian INGOs have reacted differently to this mixture of opportunities and risks involved with engaging with local faith actors: faith-based humanitarian INGOs recognize the risks and have concerns, but engage with LFAs in a strategic, ongoing basis in their work to promote local humanitarian leadership, while secular INGOs work with local faith actors primarily on an ad hoc basis and not as partners in their LHL efforts.

Yet our research suggests that, even with these different approaches, secular and faith-inspired international humanitarian NGOs have something in common: a low level of religious literacy. In other words, although humanitarian INGOs are engaging with local faith actors, they are not doing so in a fashion that is as informed or sophisticated as it should be. In order for humanitarian INGOs to engage local faith actors effectively, so as to further their work on local humanitarian leadership they should have a certain level of religious literacy, i.e., a strong understanding of how religion functions in the contexts where they work, including the following factors:

- Identifying which religious or worldview perspectives are culturally dominant and which are marginalized;

- Understanding how culturally dominant forms of religious beliefs or worldviews interact with and are reinforced by other dominant political, economic, and social forces;

- Identifying religious leaders and practitioners who are prominent and represent the culturally dominant perspectives, as well as those leaders and practitioners representing perspectives that are less prominent and/or marginalized (often women and racial/ethnic minorities) and communities whose perspective may not be well represented by leaders; and

- Recognizing how religious beliefs function as motivating factors giving ideological legitimacy to the full range of political, economic, and social expressions of human agency. 
Both faith-inspired and secular international humanitarian NGOs also need to be aware of dominant and marginalized religious perspectives within their own organizations, including the marginalization of any religious perspective within secular organizations.

Our scoping research suggests that there are significant weaknesses in approaches to religious literacy and engagement by both secular and faith-inspired humanitarian INGOs. Virtually all stakeholders recognized the importance of a greater level of religious literacy in their work on local humanitarian leadership and had in mind very clear components that would be useful, including obtaining more information about relevant religious, cultural, and political factors in a given context; learning more about local faith actors operating in the areas where INGOs are working and how those LFAs work; allowing for religiously-based discussions of human rights and humanitarian principles; recognizing secular assumptions; and examining the opportunities and risks of engagement with LFAs.

This scoping research, combining a literature review and interviews of more than 45 stakeholders, set out to examine the varying approaches and effectiveness in local humanitarian leadership by secular and faith-inspired international humanitarian NGOs, their varying approaches to partnering and engaging with local faith actors, and their religious literacy. The interviews focused on INGO staff, primarily in headquarters but also some field staff, and researchers, but also included representatives of the United Nations (UN), Red Cross, and government. Building on Oxfam's perspective and network, they were designed to provide the INGO and international actor perspective on these issues.

Following from this research, we recommend the following:

1. Practitioners and scholars should collaborate to create a religious literacy curriculum, or toolbox, in order to improve their humanitarian work generally and their local humanitarian leadership work in particular. It should:

- Be comprehensive, focusing not only on the key principles, beliefs, doctrine, and history of religions, but-more useful for an industry where people work in many different contexts-it will provide aid workers with the tools to gather this information, as well as key information about the relationship between religion, politics, and culture in a given context.

- Consider issues around gender and be intersectional (recognizing the multiple layers of identity - and discrimination-that occur across race, gender, social class, ethnicity, sexual orientation, religion, age, etc.).

- Reflect the internal diversity of many religions.

- Include discussions of secular literacy.

- Be sufficiently flexible to meet the needs of various actors, including secular and faithbased INGOs.

2. Both secular and faith-inspired humanitarian INGOs should examine and seek to address their own religious biases in their work on local humanitarian leadership as well as their other humanitarian work. Religious biases may include privileging particular religions or particular expressions of religion as more valid than others; they may include biases against secularism and secular worldviews. Secular biases may include a predisposition to considering religious spaces as unwelcoming and participating in religious spaces as a violation of their secularity. It is important to note that religious and secular biases may differ between headquarters and field offices, among field offices, and between national and international staff in field offices. International practitioners (and local faith actors) should give careful consideration to the "non-negotiables," from their respective points of view, of engaging with each other—and whether a "deal-breaker"-e.g., over gender or impartiality - would preclude collaboration on that particular area of work or would preclude partnership generally.

3. Practitioners and researchers should work together to prepare an analysis of the potential costs of not engaging with LFAs in local humanitarian leadership work.

4. When engaging with local faith actors, INGOs should:

- Keep in mind that many local faith actors are not primarily humanitarian actors. They are not smaller versions_clones or "mini-me's"—of the big INGOs, and they may have no interest in becoming such. Yet, while they may not have humanitarian 
experience or while their approaches to delivering assistance may differ from international humanitarian standards, they do have many assets to bring to bear, potentially including experience delivering social assistance to communities, capacity and expertise in other areas, networks, access, and clout within their communities. Both parties can certainly learn from each other.

- Do not presume that religious leaders and LFAs represent everyone in their communities, particularly the most vulnerable. This is true even if the leaders and local faith actors are put forward by the government.

- Always look out for leadership outside of institutional hierarchies. While women are leaders in some faiths, they are often not part of the traditional hierarchy. In such instances they should be sought out, e.g., in women's faith groups.

- When discussing issues related to human rights and humanitarian principles, a) avoid jargon and speak in terms that are widely, and locally, understandable; b) do not presume that these values are universally held or interpreted the same by all; but also c) do not suggest that international actors have the copyright on such values.

- Watch out for unintended instances where potential beneficiaries are reluctant to obtain assistance from an LFA because of a perception of partiality.

- Be aware of the risk of instrumentalizing local faith actors, i.e., exploiting their capacity and resources by using them to accomplish the INGOs' goals, particularly when those goals vary from the LFAs'.

5. In order to collaboratively explore the risks and opportunities of engaging with local faith actors, secular and faith-inspired humanitarian INGOs should consider joining initiatives such as the UN Interagency Taskforce on Religion and Development, ${ }^{5}$ the Joint Learning Initiative on Faith \& Local Communities (JLI), and the Partnership for Religion and Development (PaRD), and participating in conferences such as the upcoming October 2017 conference "Localizing Response to Humanitarian Need: The Role of Religious and FaithBased Organizations."

6. More in-depth research should be conducted to examine how faith-inspired and secular humanitarian INGOs engage in local humanitarian leadership and to learn lessons for this work. It should focus on:

- The risks and opportunities of engagement by humanitarian INGOs with local faith actors in local humanitarian leadership work. The research should include, or be supplemented by, an examination of lessons learned from the development sector as well as from multilateral institutions and government aid agencies that engage with LFAs.

- Whether there are other differences, beyond engagement with LFAs, in the practices and effectiveness of the local humanitarian leadership work conducted by secular and faith-inspired humanitarian organizations. This should include whether the INGOs are playing a role as intermediary between local faith actors and larger INGOs. This research should focus heavily on obtaining the perspectives of actors based incountry: field staff of INGOs and other actors and, particularly, local secular and faith actors. 


\section{INTRODUCTION}

\section{LOCAL HUMANITARIAN LEADERSHIP}

As research from Oxfam and others has found, the global international aid system-led by the UN, the biggest government donors, INGOs, and the Red Cross-has saved countless lives and alleviated suffering wherever possible, but it is deeply flawed. It can be slow to respond to emergencies; it is costly; and it often demonstrates more accountability to its donors than to the people it aims to help. It has not effectively prioritized DRR. And although its international staff members have much to offer-such as technical skills and the willingness to spotlight violations of human rights - they can lack awareness of local needs, priorities, and culture. ${ }^{7}$ As a result of these structural flaws, the system is not as efficient as it could be in saving lives, and it often strips away the dignity of beneficiaries in the name of saving their lives. ${ }^{8}$ Furthermore, research shows that due to climate change, humanitarian needs are growing and are expected to continue to climb at a pace that cannot be matched by the current global system. ${ }^{9}$

A fundamental transformation is needed in the way humanitarian assistance is conducted. Toward this end, Oxfam and many others have embraced local humanitarian leadership (LHL): the concept that humanitarian action that is led by governments in countries affected by crises, assisted and held accountable by local civil societies and assisted by international actors, will often save more lives because it is faster and often more appropriate. Also, as a rights-based organization, Oxfam embraces LHL's placement of decision-making in the hands of the people most affected by crises. ${ }^{10}$ Of course, LHL is not possible in all situations, such as where governments are party to a conflict, committing human rights and international humanitarian law violations, or not providing humanitarian assistance in an impartial manner to all people, regardless of their ethnic, political, or religious affiliation. But even in those instances, the international community should change its modus operandi so that it looks first to assess existing capacity on the ground before taking the lead in humanitarian action, and so that it is always focused on strengthening that local capacity.

Bringing about this transformation-so that the default becomes local leadership and the exception becomes international leadership_-will require the shifting of knowledge, power, and resources to local and national humanitarian actors (LNHAs) (see the definition of LNHA and other terms on page 11). Locally led humanitarian action was one of the most prevalent themes at last year's World Humanitarian Summit. Among the strengths of the Summit were the participation of many local actors and commitments made by international organizations about moving toward more LHL, ${ }^{11}$ but the heavy lifting lies ahead. Many LNHAs need to bolster their leadership, organizational, and technical capacities so that they are able to lead humanitarian action, absorb more direct funding, conduct fundraising, and meet the reporting requirements of donors. Many national governments must invest more funds in DRR, preparedness, and response and to ensure that they are sufficiently protecting, and providing equitable and impartial humanitarian assistance to, their people. INGOs need to 1) provide more direct funding, including core funding, to their local partners; 2) conduct smarter and more strategic capacity strengthening; 3) be better partners, including creating the space for LNHAs to engage more in all aspects of planning, implementation, and monitoring, evaluation, and learning (MEAL) of particular projects and to engage in national- and international-level conversations about humanitarian action and LHL; ${ }^{12}$ 4) promote their partners to their donors; and 5) devise a new business model for their work going forward that capitalizes on the value they add to the system. Multilateral agencies must do many of the same things. Donors need to be willing to shoulder more of the financial risk that is inherent in humanitarian action, easing unnecessary legal and policy hurdles to direct funding by LNHAs, creating more flexible funding opportunities and access to opportunities in local languages.

This work will not be easy, and it will require organizations and agencies in each of these groups to step forward as leaders. Interestingly, faith-inspired humanitarian INGOs predominate in the INGO discourse on LHL. Among the signatories of the Charter for Change are Christian Aid, Tearfund, Islamic Relief (IR), multiple Caritas chapters including Catholic Relief Services (CRS) and the Catholic Agency For Overseas Development (CAFOD), and multiple Church Aid chapters, while Oxfam and Care are the exceptions as large secular humanitarian INGOs. ${ }^{13}$ FIOs are also predominant among the INGO thought leadership on LHL. ${ }^{14}$ 
In order to affect meaningful change toward a system where local humanitarian leadership is the default, international actors in particular will need to take steps that run counter to their most immediate, entrenched interests. Currently, LNHAs receive only a fragment of total humanitarian funding, while the overwhelming majority goes to multilateral agencies and INGOs. ${ }^{15}$ In turn, multilateral agencies and INGOs pass much of this funding to LNHAs (often the multilaterals channel funds first to INGOs, who then pass them to LNHAs), but they keep a portion for overhead expenses and usually some project-related costs. ${ }^{16}$ We also need to recognize the neo-colonialism and paternalism that are sometimes (but certainly not always) latent in the resistance to local leadership, leading many Northern donors and Northern-based INGOs to find it difficult to imagine Southern governments and civil society being able to lead humanitarian action effectively without their oversight. ${ }^{17}$

Donors, multilateral agencies, and INGOs must also come to terms with the fact that LNHAs may not all look like the typical humanitarian NGO from the global North. Nowhere is this more true than when it comes to understanding the roles of religion in different contexts and the roles of local faith actors, which range from a church, mosque, or temple, to a small faith-inspired community-based organization to a local NGO.

\section{LHL, Religion, and Religious Actors}

How does an understanding of religion in general and of local faith actors in particular fit into the humanitarian landscape? We know that religion continues to play an extremely important role in the lives of people around the world. Despite predictions to the contrary 50 years ago, the global South, where people are most vulnerable to the effects of climate change, natural hazards, and conflicts, is becoming more religious, not less. ${ }^{18}$ Local religious institutions and faith-inspired organizations play myriad roles, sometimes fueling and sometimes mitigating conflict situations, yet consistently providing social services and relief in disaster and conflict contexts. They have enormous capacity. As one researcher put it, "[Religious actors] don't need capacity building. They are capacity. They're walking, talking capacity. They're real experts. They just haven't applied that expertise in this particular kind of setting before." ${ }^{19}$ It is important to recognize that religious institutions and actors have substantial capacity for humanitarian assistance, yet they do not function primarily as humanitarian actors, and they often are not NGOs. ${ }^{20}$ They often operate in parallel worlds from the "international" system, receiving funding through different channels and not coordinating with the international actors, or even sometimes the local and national secular actors. They are also guided by different values, some of which overlap with the principles guiding humanitarian action.

In many societies, it is the religious leaders and actors who are the most powerful and respected members of the society, with tremendous access to, and sway over, their community members. Yet many secular international humanitarian actors keep religion and local religious actors at arm's length, even as they embrace the LHL agenda and work to strengthen the capacity of local actors in the places where they work to lead humanitarian action.

There are a number of reasons for the reluctance on the part of many international humanitarian actors, including some faith-inspired ones, to engage with local religious leaders and local faith actors. In our current political context, where Islamophobia is rampant, ${ }^{21}$ some people connote religion-especially Islam—with extremism and religious violence. Others worry about faithinspired organizations, particularly local ones, engaging in proselytizing or a quid pro quo in return for humanitarian assistance. Others know that people in many parts of the world have a fear of institutional religion and are concerned that such people will be reluctant to accept assistance from faith-inspired organizations or religious institutions. Yet others do not know how to engage with local faith actors: who they are, the protocols of reaching out and communicating with them, etc. These and other factors lead to discomfort, reluctance, wariness, and even disdain for engaging with religion and religious actors among many international humanitarian workers, notwithstanding the fact that many are engaged in the same type of work, often motivated by the same values, and working toward the same goals. 


\section{PROJECT AND METHODOLOGY}

In this project, Harvard Divinity School's Religious Literacy Project (RLP) and Oxfam have examined how humanitarian INGOs engage with issues related to religion and religious actors in their work on local leadership, what assumptions are behind those policies and practices, and the opportunities and challenges presented by those policies, practices, and tools. More specifically, we have considered:

- Whether there is a difference in how secular and faith-inspired humanitarian INGOs think about, and are working toward, LHL;

- Whether there is a difference in how secular and faith-inspired humanitarian INGOs engage with local faith actors in their LHL work; and

- The level of religious literacy (defined below in the Terminology section) existing in humanitarian INGOs, the approach (including tools) they employ, and whether a greater level of religious literacy would facilitate their LHL work.

This project was designed as scoping research, a modest piece of research to scratch the surface of this issue and see "if there's something there" that should be explored more deeply and comprehensively.

The selected research methods were:

- A literature review of approximately 100 peer-reviewed and other journal articles and over 50 white papers, NGO reports and website pages, etc. ${ }^{22}$

- Interviews and conversations with over 45 policymakers and staff in humanitarian INGOs (both faith-inspired and secular, in headquarters and field offices), UN agencies, the Red Cross movement, government aid agencies, and academic leaders. (See list of people interviewed and consulted in the Appendix.) The interviews took place between November 2016 and February 2017 and employed a qualitative, semi-structured, problem-centered interview method. ${ }^{23}$

- A search for, and examination of, tools utilized by INGOs in their work on local humanitarian leadership and for religious literacy.

- A day-long workshop of 15 practitioner and academic experts, who discussed the research questions and vetted the preliminary findings.

As the research questions suggest, the focus of the research is predominantly on INGO behavior and INGO views of LFAs. As such, the interviews of humanitarian practitioners were primarily with INGOs, and secondarily with other international actors in order to obtain their perspectives on the behavior of the INGOs vis-à-vis LHL, engagement with local faith actors, and religious literacy. We did not interview local actors. Seeking a largely top-down view of the current system, most of the interviews with INGO staff were with humanitarian leadership of the agencies, based in headquarters, although we did interview a number of field-based Oxfam staff. Interviews with more field-based INGO staff and local actors (secular and faith-based) would be an important area of further research that would provide a more comprehensive perspective on these questions.

Limitations on the methodology include the small sample size: we did not interview all of the key stakeholders by any means. We were able to interview representatives of about 15 international humanitarian agencies and, within these, we generally interviewed only one representative from each organization with the exception of Oxfam. Within the INGO interviews, the number of FIOs was greater than the number of secular organizations, allowing for greater representation of views on the research questions by FIOs. Within FIOs, Christian organizations predominated, and we were able to speak with only one Muslim, one Jewish, and one Buddhist humanitarian INGO. The vast majority of INGO representatives were from Northern-based INGOs, with only one Southern-based INGO represented. The INGOs represented are large and work globally. All interviews were conducted in English, which is not the native language of some of the interviewees, particularly field-based humanitarian INGO staff, and there were some issues around comprehension of both questions and answers.

All qualitative research is, of course, influenced by the perspectives of both the researchers and research subjects. Although our interviews attempted to avoid using language that could be interpreted differently by different people, ${ }^{24}$ this research topic revolves around such terms, and 
it was clear that there were some misunderstandings. The problem-centered methodology employed for this research did not presume a false neutrality but rather acknowledged its own perspective as being conducted by a secular NGO that has a reputation for supporting and advocating for the LHL agenda; different interviewers might obtain a different perspective from interview subjects.

\section{TERMINOLOGY}

Many of the terms introduced above are complex, holding different meanings and connotations for different people. We use the following terms and definitions:

- Local humanitarian leadership (LHL), or locally led humanitarian action: Humanitarian action that is led by governments in countries affected by crises, assisted and held accountable by local civil societies, and assisted by international actors.

- Religious literacy: Sometimes referred to as "faith literacy" or "cultural literacy/competence/sensitivity," the term "religious literacy" as we define and use it in this research, encompasses:

- A basic understanding of the history, central texts (where applicable), beliefs, practices, and contemporary manifestations of several of the world's religious traditions and expressions, that reflects their internal diversity;

- An understanding that all of the above are influenced by the society, culture, and history of a particular context, and that they evolve and change with time; and

- The ability to discern and explore the religious dimensions within the society, culture, and politics of a particular context. ${ }^{25}$

- Local actor, or Local and National Humanitarian Actor (LNHA): ${ }^{26}$ Domestic government, civil society, and community-based organizations. These organizations and entities may operate in one community (at the "local" level), a region of the country, or nationally. They include local religious actors (see below). Stakeholders differ widely in their conceptualization of "local actor," with disagreement on whether it includes government entities, diaspora groups, country offices of INGOs, and national Red Cross/Crescent chapters. Others feel that the term "local" itself is problematic, either because it creates confusion in whether it signifies the community level or anything at the national or lower level, or because it is belittling. Some of these issues are currently being debated on the global stage, through the discussions on the Grand Bargain commitments, and hopefully the humanitarian community will move toward a consensus.

- Humanitarian INGO: An INGO whose work is exclusively humanitarian action or a "multimandate INGO" whose portfolio includes development work as well.

- Faith-based NGO (FBO): An NGO that has an explicit faith claim in its mission statement and/or is directly supported by a formal religious structure. ${ }^{27}$

- Faith-inspired NGO (FIO): We use this term to refer to either an FBO or an organization with links to religious institutions and communities. FIO is a broader term that includes FBOs but also includes organizations that operate independently from a formal religious institution. ${ }^{28}$

- Local religious actor, or local faith actor (LFA): For our purposes, this is a "catch-all" term for religious institutions, communities (see below for definitions), and FIOs with a religious purpose operating at a national or sub-national level in a country.

- Local religious institution: Domestic formal structures of religious traditions and communities, religiously inspired movements, community- or congregation-level groups, faith-inspired and faith-based organizations, and religiously linked academic institutions.

- Local religious community: Local affiliation group of a religious tradition or organization.

- Secular humanitarian INGO: ${ }^{29}$ We use this category to capture all humanitarian INGOs that are not faith-inspired. It should be noted, however, that "secularism is not neutral and universal, that different types of secularism exist and that secularism is viewed differently around the world. ${ }^{30}$ Furthermore, since "secularism" is often used to connote a foundation in human rights, many FIOs in fact consider themselves to be "secular" in addition to faithinspired. 


\section{SECULAR AND FAITH-INSPIRED HUMANITARIAN INGOS AND LHL: DIFFERENCES IN DISCOURSE BUT NOT EFFECTIVENESS}

In this research, we have considered the ways in which the religious or secular motivations and practices of humanitarian INGOs impact their approach to working with and through local actors and to LHL. ${ }^{31}$ In this section, we highlight two issues that have arisen in our interviews and literature review: 1) strategies and practices toward LHL, and 2) the effectiveness of LHL work. In this and the other areas of our analysis, we do not mean to suggest a) a uniform split between FIOs and secular NGOs on any issue, or b) that either group is homogeneous in its perspective.

Not all humanitarian INGOs support the move toward local humanitarian leadership, and this was the case within the organizations interviewed in this research. Some such organizations do not believe that LHL is an effective or appropriate approach, at least in their particular work, although even some of these recognize that they should improve their understanding of local contexts. $^{33}$ The overwhelming majority of the humanitarian INGOs interviewed in this research do, however, support the LHL agenda.

Most respondents expressed a belief that there is no significant difference in the strategies to LHL employed by secular humanitarian INGOs and FIOs, ${ }^{34}$ and the literature does not suggest any difference either. ${ }^{35}$

Our research did highlight two potential differences in the practices employed by these groups in their LHL work. One is the engagement with local faith actors, which is discussed in detail below. The other difference in the discourse-and possibly the practice-of secular and faithinspired humanitarian INGOs around LHL is the emphasis on the practice of serving as intermediary organizations for local actors. Several FIO respondents, including from Islamic Relief, CRS, and World Vision, noted that local faith-inspired organizations and institutions frequently perceive a "gap" between themselves and large, humanitarian INGOs. ${ }^{36}$ FIO respondents discussed how their field-based colleagues and partner organizations feel "alienated" and/or as if they work in "parallel systems," based on their lack of information and the fact that they do not operate in the same networks as secular actors at the local, national, or international level. In its partnerships with local faith institutions, CRS, for example, helps them link into the global infrastructure, including showing them how to access help and how to have influence. In order to name and analyze how FIOs often work to bridge this gap, Kathryn Kraft at the University of East London is currently conducting research on the role of "intermediary" organizations, i.e., medium-sized INGOs that play a vital role in translating between the different languages and operational procedures of international and small, local actors. ${ }^{37}$ While LFAs are not the only LNHAs who feel excluded by the UN-led, global system and FIOs are not the only organizations that could play the role of intermediaries, FIOs were the only INGOs to mention this role in the interviews. ${ }^{38}$ Kraft believes that the ability of FIOs to engage the religiosity of local organizations and faith institutions makes them particularly well suited for the role. She argues that such intermediaries play a key role in enabling LHL by LFAs, by bridging the aforementioned gap as well as protecting the specific leadership capacities of local organizations and institutions. ${ }^{39}$

Yet despite this difference in the discourse around LHL strategies and practices, neither FIO representatives nor other stakeholders could offer any evidence that the faith motivation and approach to LHL of FIOs make them more effective. There is also no evidence in the literature, notwithstanding research having been conducted looking for evidence of the effect of faith on LHL. ${ }^{40}$ There is a rich discussion about whether faith-inspired humanitarian INGOs are more effective in their humanitarian assistance work because of cultural proximity-i.e., that their religious foundation gives them an advantage in terms of increased trust with populations, logistical access to communities, and security_but this discussion is about INGOs' direct 


\section{PARTNERING WITH LOCAL FAITH ACTORS IN LHL WORK: DIFFERENT APPROACHES, SAME COMPLEXITY}

This research examined the scale and nature of humanitarian INGOs' partnering with local faith actors, attempting to discern a difference in the "ways of working" of international secular and faith-based INGOs, as well as the potential advantages and risks of such engagement. This issue relates directly to local humanitarian leadership because it sheds light on the local actors that INGOs are supporting and promoting to take on a larger role in locally led humanitarian action in a given country.

\section{Scale and Nature of INGO Partnerships with Local Religious Actors in LHL Work: Differences between Secular and Faith- Inspired Humanitarian INGOs}

All INGO representatives interviewed expressed a willingness to engage or work with local faith actors on some level; no respondent or organizational policy report indicated that any organization maintains a position against working or, indeed, partnering with local faith actors. The power analysis by INGOs to determine whether and how to collaborate with local faith actors appears to be similar to the analysis of whether to engage with other political and social actors. $^{42}$ The representatives of faith-inspired humanitarian INGOs, however, while equally aware of the risks of engaging with local faith actors, often indicated a greater institutional willingness than their secular counterparts to conclude that the opportunities outweigh the risks.

Yet this scoping research suggests there is a difference in the networks of local actors to which FIOs such as Islamic Relief, CRS, and Samaritan's Purse are connected that results in more systematic and strategic partnerships with local faith actors, a finding substantiated in the literature. ${ }^{43}$ Almost all of the faith-inspired humanitarian INGOs interviewed work with a network of associated LFAs in the countries where they work, even if they also engage with secular LNHAs, including government entities, on an ad hoc or ongoing basis. For example, Samaritan's Purse works primarily with Christian-based local NGOs, CBOs, and local grassroots church networks, although they work with secular LNHAs as well; Tearfund prioritizes partnerships with local church congregations, church networks, and faith-based NGOs, in that order; Islamic Relief tends to work with local Muslim CBOs, but also works with secular partners and those of other faiths; and the Adventist Development and Relief Agency (ADRA) is committed to working with national ADRA organizations as well as through networks of Adventist congregations and volunteers. ${ }^{44}$ They all work globally and provide services to populations of different denominations and faiths. According to Samaritan's Purse, for example, "Because we have local partnerships-many of them faith-based partners, so local grassroots church networks and such-in over 130 countries around the world, we can send in trained disaster responders. They hit the ground running, plug into those networks, and are able to respond very, very quickly." 45 And this links to the organization's LHL work:

In sudden-onset disaster response, we have local partners, some we have invested in for decades, others for a shorter period . . . Our first port of call when a disaster happens is plugging into those networks, plugging into those partners, seeing what capacity they have, seeing how much investment we have put into them over the years that we've partnered with them, seeing what they're able to do in terms of responding to that disaster. Then our role [is] very much being a supplement to that.

In some situations, the local partners' capacity may be fairly limited and so they'll need a lot of input from our international body: sending out trained expert disaster responders, supplies, all sorts of stuff. The focus there for the local partner would be more on the learning side, and more assisting us with the response, and building their capacity for the next time that something happens in their locality. 
But where we have a partner who is a lot stronger, and we've developed a greater relationship with, and had more time to invest in them, then our disaster response would very much be coming along and supporting them in how they see the most appropriate way of responding to that disaster in their context to be. It may be we send in a handful of experts that supplements their team of experts. It may be that we fund relief supplies for them. It may be something else. It can vary very much.

We have the ability to nuance our disaster response depending on the capacity of the local partner. So the first thing we look at is where has the disaster happened, what local partner do we know on the ground, how strong are they, how able are they to respond to this disaster in the way that is needed, and then our response is determined based on that factor. ${ }^{46}$

By contrast, the secular INGO representatives spoke only of ad hoc engagement with LFAs when their interests align; none identified an LFA as among their strategic partners, although Oxfam, for example, said it was a possibility. For Oxfam, engaging with LFAs "depends on the context. There is no rule of whom we should or shouldn't engage. In some contexts religious actors are more active or more relevant ... and so there is engagement at that level. And sometimes at the community level we interact with traditional leaders, many of whom are also religious leaders." 47 Save the Children similarly works with a "full range" of religious and religiously inspired groups, including religious institutions. ${ }^{48}$

\section{Advantages of Engagement by INGOs with Local Religious Actors in LHL Work}

Both secular and faith-inspired humanitarian INGOs, as well as other stakeholders interviewed, offered a number of reasons to engage with local religious actors in their humanitarian assistance work generally, and in work around LHL in particular. Many of these parallel the reasons that local actors in general should play a larger role in leading humanitarian action in their countries.

First, some stakeholders have expressed the view that INGOs should engage and partner with LFAs because LFAs are often the first responders in a crisis and often have unparalleled access through their networks and because, in settings of conflict or constrained civil society space, they can often operate under the radar (as compared to INGOs) ${ }^{49}$ In fact, because many faith actors do operate under the radar because of the disconnect between the global system and that of LFAs, many international actors are unaware of the existing capacity within LFAs. ${ }^{50}$ As a CRS representative described, "[LFAs] work under the radar and more often than not outside of the humanitarian infrastructure or ecosystem, so it's not like you're going to run into them in a coordination meeting. And so they're doing their job, and they're doing it quietly, and they often have trouble having that interface and connection to the wider humanitarian sector." ${ }^{51} \mathrm{~A}$ former official of the Office of the UN High Commissioner for Refugees (UNHCR) referred to the UN-led humanitarian system as being "olympically unaware of the importance of faith-based actors and a whole range of services." 52

Second, the ability to dialogue with religious leaders about religious and cultural causes and impacts of humanitarian crises, and the religious leaders' ability to engage in public health and other messaging with their communities, can be invaluable. The most frequently cited example in this regard is the Ebola epidemic in West Africa. Multiple interviewees were quick to point out how the (primarily faith-inspired) organizations that maintained regular dialogue with local religious leaders were among the first to identify the causal link between traditional burial practices and the spread of the Ebola virus. ${ }^{53}$

Similarly, many interviewees point to the ability of faith-based INGO representatives, through their close relationships with LFAs and local religious leaders in particular, to influence social and religious traditions and behaviors that have an impact on humanitarian and development issues such as gender equality, early marriage, climate change, and HIVIAIDS. ${ }^{54}$ Organizations such as Christian Aid, Islamic Relief, Tearfund, and ADRA all identified engaging in a practice described by Christian Aid as "in-house" theology: on issues deemed appropriate and useful, these organizations will initiate discussions within their organizations on beliefs or practices that reinforce humanitarian problems in certain contexts and consider ways to change local perspectives. ${ }^{55}$ Tearfund engages with theological questions both with an in-house theological consultant and a theological panel. Islamic Relief has done extensive research on various humanitarian issues (e.g., gender, child protection, climate change) and has worked with a 
range of Muslim leaders to develop perspectives on those issues from a theological and Quranic basis. They use these perspectives in the training of staff and the implementation of projects. IR also takes this one step further: when the organization encounters a religious belief or practice (e.g., domestic violence) that is inconsistent with their humanitarian and human rights framework, they organize fora for religious leaders to gather and discuss the topic. Because religions are internally diverse, IR is often able to find religious leaders in the surrounding area that are more supportive of their humanitarian goals with respect to that practice. Then, rather than force IR's position on local religious leaders, they allow a space for dialogue that can lead to positive change. ${ }^{56}$ These examples suggest that efforts to strengthen the leadership capacity and voice of local religious leaders and LFAs could increase our knowledge base and community support for preventing, responding to, and recovering from humanitarian crises.

There is no reason in principle that secular INGOs could not engage in such a practice with LFAs, and one Oxfam representative recounted that, in Oxfam's campaign against violence against women (VAW), the organization engaged religious leaders to denounce VAW through scripture and principles that criminalized violence from a religious perspective. ${ }^{57}$ Yet secular INGOs may not feel comfortable in that role, and LFAs may not welcome such an intervention from a secular organization, particularly one that is viewed as hostile to religion. ${ }^{58} \mathrm{As}$ a different Oxfam representative described (reflecting the heterogeneity within organizations), "Oxfam's mission is not to change religious institutions but to deliver aid impartially."

Finally, although this is not about LHL but about humanitarian action generally, there is the notion that if international actors are truly listening to people in affected communities, who say their spiritual needs are vitally important to them in a crisis setting, it is important to engage with LFAs, who attend to the spiritual needs of affected people and not merely their physical, social, and emotional needs. ${ }^{60}$ Under this logic, the American Red Cross has relationships with leaders of the major religions, upon whom they call to provide counseling to people facing trauma and loss. ${ }^{61}$ As scholar Alastair Ager voiced the question to Oxfam: "Oxfam isn't just about food and drink: it thinks about livelihoods; it thinks about rights. But if there's a whole aspect of the whole person that Oxfam doesn't feel comfortable to engage with, the question has to be: can that part of that human still thrive? Are there enough resources there? And on what grounds does Oxfam exempt itself from [religion and faith]?" ${ }^{\prime 2}$

\section{Risks and Concerns of Engagement by INGOs with Local Religious Actors in LHL Work}

Stakeholders-often the very same ones articulating the benefits set out above-offered a number of concerns and risks regarding engagement with LFAs in local humanitarian leadership work.

First, there is a concern about the capacity of LFAs to meet technical humanitarian standards. ${ }^{63}$ Again, these LFAs could be churches or mosques or small CBOs, not water, sanitation, and hygiene (WASH) engineers or shelter experts-although they could also be faith-inspired NGOs. Christian Aid does not tend to work directly with churches for this reason, because they are "not set up to deliver relief . . . on a large scale" and some of the churches "don't have the professional background or . . the striving for professionalism," which is "very, very difficult to insert . . . as an afterthought.." ${ }^{64}$ Recognizing that "the plethora of standards is . . really difficult for any national NGO, local network of dioceses, or . . . a local church to understand," for example, Tearfund has synthesized international standards and principles into their own set of 12 Quality Standards. Mechanisms and processes to program strengthen capacity, and measure against these standards are in place for all partners in emergency settings. However, when it comes to the lowest tier of working through churches and low-capacity faith partners, these are reduced down to three minimal "non-negotiables": values (which mirror humanitarian principles from a faith perspective, with heavy emphasis on issues of fraud, corruption, and abuse), targeting (integrating the need for impartiality into daily programming such as needs assessments), and accountability (e.g., dignity, ownership, participation, equality). ${ }^{65}$

Second, there is a concern about the absorptive capacity (i.e., ability to scale up) of LFAs, particularly religious institutions and small, local faith-inspired CBOs ${ }^{66}$ Alastair Ager shares an example of churches in Zambia that received a grant and "essentially blew up;" "money was dumped on them ... and it was not good for them." ${ }^{67}$ This concern has been voiced in support of the importance of faith-inspired INGOs in particular serving as intermediaries between LFAs 
and the big INGOs and funders, so as to "let the church be the church," in Kathryn Kraft's words. Furthermore:

Maybe this flies in the face of what people want with the localization agenda, but it's one thing to say let's work together to meet the needs of these drought-affected people during the next three months. It's another thing to say we're going to start inserting ourselves into the way you function for the next five years because we want you to be disaster-risk ready and capable of managing a bigger grant later on and they are like, "Wait a second, we're a church, not an NGO.",8

Third, there is a widespread concern about the willingness and ability of LFAs to adhere to the humanitarian principles, particularly impartiality and neutrality, and to avoid proselytizing, when carrying out humanitarian work. Different humanitarian actors subscribe to different humanitarian principles, but the four principles considered core are humanity (that human suffering must be addressed wherever it is found), independence (not acting as instruments of a government's foreign policy), impartiality (prioritizing aid based on need alone and without respect to the race, religion, or nationality of the recipients), and neutrality (traditionally that humanitarian actors must not take sides in hostilities but more recently often narrowed to the notion that they should not use aid to further a particular political or religious standpoint). ${ }^{69}$

Many humanitarian actors, including Oxfam, are raising questions about the continuing relevance and particularly the inconsistent application of some of the principles. ${ }^{70}$ For example, as a rights-based organization, Oxfam intentionally does not adhere to the principle of neutrality, as traditionally defined: ${ }^{71}$ indeed, neutrality has not been included as a core principle in the Core Humanitarian Standard. ${ }^{72}$ There are also different definitions of the principles, which complicate any analysis and discussion. The implications of the principle of impartiality, for instance, depend largely on the geographic area in question: few INGOs can claim to give impartial assistance on a global scale, given the inequality in funding across crises and, within particular crises, INGOs are often unable to deliver assistance impartially due to constraints on access caused by security concerns or obstructions by government or other armed actors. ${ }^{73}$ As one researcher remarked, "The challenge . . . is who is measuring impartiality." ${ }^{74}$ Furthermore, there is a tendency to hold local actors to a standard not required of international actors—or, viewed another way, to overlook the not-infrequent evidence of transgressions of the principles by international actors. ${ }^{75}$

Notwithstanding this debate, the unwillingness or inability of local actors, including local faith actors, to adhere to the humanitarian principles (particularly neutrality and impartiality) is often offered as a criticism of a global shift toward LHL. ${ }^{76}$ There are two important questions in this regard: whether there is a real basis for concern about the impartiality of local faith actors, and whether the perception of partiality of local faith actors by potential beneficiaries of other faiths or no faith risks impeding the impartial delivery of humanitarian assistance. First, as with all local actors, it may be difficult for local religious actors to act impartially for several reasons, including limited or no access to areas with a different population. There may also be great pressure put upon local religious and secular actors to give preference in their distribution of assistance to people of their religion, ethnicity, political affiliation, etc. This pressure may be heightened in countries where there is a state religion (and would also call into question the humanitarian principle of independence in this situation). ${ }^{77}$ Furthermore, proselytizing is widely considered a violation of impartiality, particularly if there is a quid pro quo of participating in religious activities or converting in return for humanitarian assistance. ${ }^{8}$

There is no evidence that local religious actors-or local actors of any kind-are more likely to act partially than international actors. Representatives of secular and faith-inspired INGOs, as well as representatives of other types of organizations, did acknowledge the stigma, however, that FIOs, and LFAs in particular, do not act impartially; ${ }^{79}$ without any basis in fact, it appears that Muslim organizations are most often the targets of this bias. ${ }^{80}$ But many respondents offered their opinions and first-hand anecdotal evidence of partiality and proselytism regarding actors from all religious traditions, ${ }^{81}$ especially outside of the immediate relief phase of a sudden-onset crisis like an earthquake or cyclone. ${ }^{82}$

Other respondents made the point that the humanitarian principles, and discussions around human rights as well, are viewed by some LFAs as "Western" and themselves value-based, and they are often presented by international actors with an air of superiority. ${ }^{83}$ As the Humanitarian Director of Oxfam suggested, "We need to look in the mirror. We claim to be the ones who are neutral and impartial, and that can come across with an air of superiority." ${ }^{84}$ In fact, however, 
many humanitarian principles overlap in many respects with the religious values that guide LFAs - values that have been in existence since long before the humanitarian field was born. ${ }^{85}$ Such stakeholders suggest that it would serve all interests if international actors attempted to translate the principles into language that LFAs will understand and if they speak with some humility, not presuming that these are new or foreign concepts to religious people around the world. ${ }^{86}$

There is a separate question around the perception of partiality of local faith actors: several interviewees reported that potential beneficiaries are sometimes scared, reluctant, or uncomfortable with receiving assistance from an FIO if they are of another or no religious affiliation. ${ }^{87}$ Christian Aid reported that they have difficulties working in some places because of the assumption that they are there to proselytize. ${ }^{88}$ This issue raises important questions about the ability of FIOs to provide truly impartial assistance, despite their best intentions, and requires further study. ${ }^{89}$

Fourth, many humanitarian practitioners and scholars worry about the assumption that the religious leaders of a community actually represent the entire community, including marginalized voices. ${ }^{90}$ As one interviewee put it, this is especially a concern given that religious leaders are typically "men with beards." ${ }^{91}$ Although the reference to beards reflects certain religions, the point is that most formal religious leaders across traditions are male.

Several respondents suggested that there is additional cause for skepticism when international actors label specific faith leaders as "legitimate" representatives. ${ }^{92}$ In the current political climate, which is laden with Islamophobia, certain, primarily Muslim, religious leaders who actually do represent a community are deemed "politically unsavory" and rejected as leaders. ${ }^{93}$

While many stakeholders do see the issue of representation as a concern, they also had a number of solutions and work-arounds. Foremost, international actors should not assume that faith leaders do actually represent the community; as one interviewee cautioned, it is always important to pay attention not only to the leaders, but to the communities themselves. ${ }^{94}$ International actors should be skeptical of government-sanctioned faith leaders in particular, since leaders with broad outreach with community members are often at odds with governments. ${ }^{95}$ They should also focus on leadership outside the institutional hierarchies, primarily for gender equality purposes. ${ }^{96}$ For example, in their policy brief Gender, Religion and Humanitarian Responses to Refugees, Elena Fiddian-Qasmiyeh and colleagues identified how many women hold influential leadership roles within communities that are not necessarily recognized formally:

Traditional definitions have tended to identify people with theological and/or ceremonial authority, and yet this has largely excluded women. However, women occupy many leadership positions within and across diverse religions, often leading social outreach programmes and mobilising volunteers and refugees themselves.

Female leaders are often harder to identify because they are less publically visible than men in many contexts. However, this should not be taken as indicative of their leadership and influence. Muslim women particularly have often been overlooked as agents of change by international organisations because they do not appear to conform to a Western notion of empowered women when they wear the hijab or niqab. ${ }^{97}$

A few stakeholders suggested that women's faith groups are a strong local actor in many communities that should be considered for support by INGOs. ${ }^{98}$

Fifth, related to this is a concern about the willingness of LFAs to advocate for gender equality, women's leadership, and LGBTQ rights. In her book Global Institutions of Religion: Ancient Movers, Modern Shakers, Katherine Marshall identified gender as one of the five "gulfs" between INGOs and local faith actors, including religious institutions. ${ }^{99}$ When discussing gender, Marshall describes a complicated scene in which, from the perspective of many humanitarian INGOs, "many religious institutions are virtually the last bastions of formal (as well as informal) glass ceilings that prevent women from exercising public religious roles"-but from the perspective of many of those religious actors, including many women, "they indeed stand for a truer and deeper appreciation of the common dignity of all persons than their secular counterparts." 100 Multiple interviewees in fact suggested that gender is the issue where there is the most tension between secular and religious actors and the most difficult point of dialogical engagement. ${ }^{101}$ On the other hand, at least one researcher noted that, while religious actors are considered more "conservative" on gender equality, this does not necessarily bear out in fact 
and has not, in any event, been demonstrated. ${ }^{102}$ Here, too, language may be an issue: one UN respondent suggested that international actors might have more success finding common ground "between the human rights discourse and the religious discourse" if, instead of talking about gender-based violence and violence against women, for example, they deconstruct the concepts and talk about "saving mothers' lives."103

Finally, and this is tied very closely to the issues around local leadership, several scholars and representatives of faith-inspired INGOs, looking at engagement from the perspective of LFAs, worry about their marginalization and instrumentalization by INGOs. ${ }^{104}$ In their book Faith, Secularism, and Humanitarian Engagement: Finding the Place of Religion in the Support of Displaced Communities, Alastair and Joey Ager describe how INGOs often privatize the beliefs and motivations of LFAs (i.e., relegate them to the private sphere), marginalize them by prioritizing INGO ideas and approaches, or instrumentalize them by co-opting their resources for non-religious purposes. ${ }^{105}$ Indeed, many stakeholders interviewed for this research identified engaging religious leaders "as conduits for disseminating information," which sounds very extractive. In the Agers' view, instrumentalization can occur even if it is open and of perceived mutual benefit because the power imbalance between INGOs and LFAs risks "co-option that is extractive, disrespectful and undermines local religious communities." 106 Instrumentalization is close to the concept of INGOs using local actors merely as subcontractors, or project implementers, that we see frequently in the current global system and that local humanitarian leadership seeks to change.

As stated above, secular and faith-inspired humanitarian INGOs appear to weigh these opportunities and risks of engaging with LFAs differently, with secular INGOs largely engaging with LFAs on an ad hoc basis and FIOs entering into strategic partnerships with them. In either form of engagement, humanitarian INGOs will require knowledge and tools to guide them.

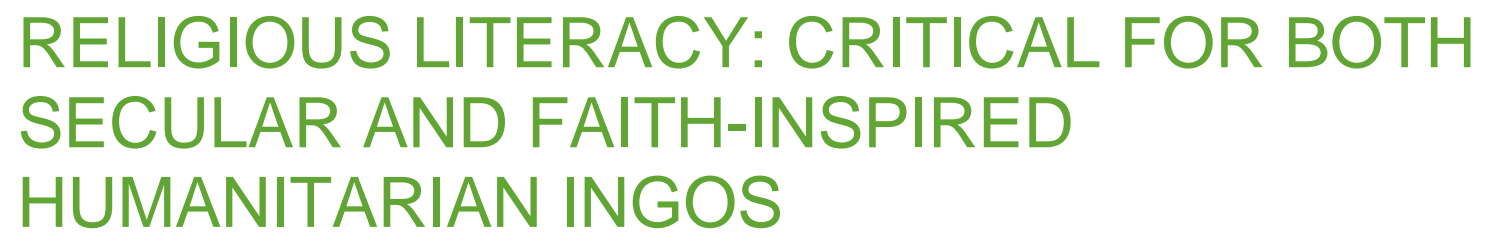

A third area of investigation for this research project has been how humanitarian INGOs approach the issue of religious literacy: whether and how organizations inform themselves about local religious beliefs and communities in the places where they work, if and how religious literacy increases INGOs' capacity to work on local humanitarian leadership, and what forms of religious literacy might lead to a more effective pursuit of LHL.

\section{What is Religious Literacy?}

The term "religious literacy," as we define and use it in this research, encompasses three elements:

1. A basic understanding of the history, central texts (where applicable), beliefs, practices, and contemporary manifestations of several of the world's religious traditions and expressions, that reflects their internal diversity;

2. An understanding that all of the above are influenced by the society, culture, and history of a particular context, and that they evolve and change with time; and

3. The ability to discern and explore the religious dimensions within the society, culture, and politics of a particular context. ${ }^{107}$

Sometimes described as "faith literacy" or "cultural literacy/competence/sensitivity," "religious literacy" refers to far more than a basic understanding of the key tenets and practices of religions ("World Religions 101"); it includes an understanding of the role of religion and religious actors in a given community. Thus it looks at religion within the context of a particular community, at a given time, and considers culture (including cultural norms and practices around gender), ethnicity, history, etc. And it is not a knowledge that one can obtain in a course and then be "religiously literate;" it is a skillset, or toolbox, that enables people-including humanitarian practitioners - to gain the relevant knowledge and understanding in the places that they work. As UN Secretary General (then High Commissioner for Refugees) António Guterres 
described it, "[T]his means a better understanding not only of the central role of faith in the communities we work with, but more concretely of faith structures and networks, and of the different approaches needed for effectively engaging with different types of faith-based actors." 108

Our research on the questions set out above has been complicated by widely varying constructions of, and experiences with, religious literacy, even by researchers and practitioners working in this space. While some participants share this broad view of the concept, others consider "religious literacy" as limited to static training on world religions to create understanding of the beliefs and practices of various different traditions. This complicated our research, because as much as we attempted to avoid the term while asking about the concept, there was some confusion.

\section{Existing Literacy Levels and Tools: Slim to None}

The interviews conducted as part of this research reflected and reported low levels of religious literacy within both secular and faith-inspired humanitarian INGOs. Statements ranged from "To be honest ... . we need to do more of that if we're really going to engage people" 109 to "Religious literacy is actually important, and we should be intentional about it and making sure that people understand it just as much as any other sort of cultural awareness so that they can be effective in their development or humanitarian work." ${ }^{110}$ An Oxfam representative expanded upon these sentiments:

We have developed a lot of tools for gender analysis, for power analysis, to assess and analyze partnerships but I think we have not been very explicit in looking at this, at the role of religious actors. And I think that we can do more to make sure it is integrated in our tools, our assessments and guidelines, our checklists, and in the briefings that we give to staff that join different humanitarian response teams where local religious factors are relevant and important. So, yes, I think there is space to be more intentional, more explicit, more thoughtful about this issue. ${ }^{111}$

A few FIO representatives report training for staff on their own religious beliefs, principles, and practices and how their respective religious tradition addresses humanitarian concerns, but nothing broader; ${ }^{112}$ some stated or implied that they take for granted a certain level of religious literacy given their faith foundation. ${ }^{113}$

While one of the goals of this project was, in fact, to search for tools or training resources that humanitarian organizations use to ensure that staff are prepared to engage local faith actors, such resources appear to be extremely rare and, in any event, not comprehensive. Few NGOs have systematic tools for training staff in religious literacy or for assisting staff in determining whether and how to engage with LFAs in a certain context. ${ }^{114}$ The same Oxfam representative made a point that was mirrored by others, saying that religious literacy training "is not part of our toolbox. If it comes to gender you can go to [our internal learning platform] Oxfam University, and you'll find 10 gender courses. I don't think you'll find any on religious actors or organizations." 115

Existing tools focus on particular aspects of religious literacy, such as standard stakeholder mapping that could be applied to faith actors, ${ }^{116}$ partnering, ${ }^{117}$ engaging in "religious theology" on certain social/humanitarian issues (including gender issues), ${ }^{118}$ and guiding LFAs in disaster response ${ }^{119}$ and working in conflict. ${ }^{120}$ Of particular relevance to this research are CRS's tools around partnerships and capacity strengthening, ${ }^{121}$ the World Bank's forthcoming guidance document, including case studies and tools, for Bank staff working at the country level on working with faith actors; ${ }^{122}$ and two resources developed by the University of Southern California Center for Religion and Civic Culture: a Religious Literacy Primer for Crises, Disasters and Public Health Emergencies, and a five-hour, web-based course co-designed with the Federal Emergency Management Agency (FEMA) titled "Religious and Cultural Literacy and Competency in Disaster." ${ }^{.123}$

\section{What's Needed?}

When asked about the potential benefits of adding or increasing religious literacy tools and training, particularly to advance work on local humanitarian leadership, respondents' answers varied. A few could not see a benefit to adding such measures, ${ }^{124}$ and a few expressed concern about adding one more thing to the "plate" of already-overworked humanitarian aid workers. ${ }^{125}$ 
Most, however, affirmed that taking steps towards increasing religious literacy would benefit their organization and others. ${ }^{126}$ As a representative of Christian Aid said, "If you're a selfrespecting, professional, international development NGO operating in another context, you have to have the tools that make you sensitive to local realities and ... the tools that help you read the local context not through a judgmental view but rather through an open willingness to encounter that other situation."

Two misconceptions about religious literacy are mentioned frequently. The first is that local actors do not need to enhance their religious literacy because local actors have this knowledge themselves. This notion has been extended to suggest that the trend toward local humanitarian leadership, which will put more decision-making in the hands of local actors, will bring both an overall increase in humanitarian decisions informed by religious literacy and a decrease in the importance of INGOs being religiously literate. These lines of thinking are problematic because local actors do not necessarily have a high level of religious literacy, which involves more than knowledge about one's own community and tradition. Furthermore, it is critical for INGOs to be religiously literate so that they can effectively navigate their engagement with LFAs and to understand the religious dimensions of the contexts in which they work, as discussed above.

The second misconception is that FIO staff do not need religious literacy training because they work for a faith-inspired organization, i.e., that they are already religiously literate. This suggestion fails to recognize the important distinction between faith actors, on the one hand, and the study of faith and faith actors that constitutes religious literacy, on the other. People of faith are appropriately trained in a particular devotional perspective of that faith whereas a religious literacy approach recognizes the internal diversity of faith and belief within and among differing traditions. Even if FIO staff have knowledge of the particular faith that inspires their organization-and there are FIOs that require that certain positions be held by members of that faith-there is no reason to believe that those staff, let alone the rest of the staff, have a high level of religious literacy.

The interviews and literature offer a wide range of recommendations on content and forms of increasing religious literacy:

- Obtaining more information about relevant religious, cultural, and political factors in a given context. ${ }^{128}$ This idea is essentially to increase organizations' attention to religious and cultural factors as a means of gaining more information about the social climate in which they work. In short, the more an organization knows about its beneficiaries, the more it can customize and tailor its capacity-strengthening activities to suit local needs. In our interview sample, this view was more commonly expressed by secular rather than religiously-inspired NGOs, although a few FIO respondents said they thought it would be important for their organization to invest in learning about other traditions, including through engaging in dialogue with religious leaders of those faiths. ${ }^{129}$ Scholar Elena Fiddian-Qasmiyeh urged the importance of any religious literacy toolbox being intersectional. ${ }^{130}$

- Learning more about LFAs operating in the areas where INGOs are working. As discussed above in Section 2, many LFAs are "under the radar" of INGOs, particularly secular ones. In light of this, some stakeholders called for mapping of LFAs, ${ }^{131}$ while others decried it, ${ }^{132}$ but many expressed the need for more information about the LFAs operating where they work. ${ }^{133}$ One suggestion voiced in this regard is that of self-mapping, i.e., mapping by LFAs themselves, which offers the benefits of LFA agency over the process, LFAs' knowledge of the local context, agency by LFAs over whether to be included in the mapping, and sustainability, yet which requires external resources and often technical support. ${ }^{134}$

- Recognizing secular assumptions and increasing organizational self-awareness. A final point made by several respondents is that one's willingness to dialogue with alternative perspectives increases one's self-awareness. Religious organizations tend to have a heightened awareness of their own assumptions and positions because they continually have to translate - and sometimes defend - them in secular humanitarian settings. Because the humanitarian system is based on a secular framework, secular organizations are not similarly forced to confront and consider the fact that there are multiple "secularisms," i.e., many reasons, motivations, and interpretations of human rights and humanitarian principles. Religious literacy that includes "secular literacy" provides an opportunity for secular groups (along with FIOs) to explicitly name what they value and how they interpret the humanitarian principles that form the foundations for humanitarian work. ${ }^{135}$ With her colleagues, Elena Fiddian-Qasmiyeh has written, "[l]t is important to recall that secularism is complex and often has many adaptations in place to accommodate religious diversity. However, secular 
worldviews are not neutral; secular worldviews also carry biases that must be acknowledged and critically examined." ${ }^{136}$ Another researcher expanded upon this notion:
A lot of the time religious literacy training isn't about teaching people religion. It's teaching people that being secular isn't the cure-all. Being secular is taking a position in itself and means that you are prioritizing some things over other things, and that can affect your work and create points of miscommunication and misunderstanding if you don't have an awareness of it. So religious literacy training in a way might be actually more useful to un-teach people about their secular presumptions rather than teach people about specific parts of religion."137

\section{- Allowing for religiously-based discussions of human rights and humanitarian} principles. In her book on religious institutions, Katherine Marshall points to the comment of Catholic philosopher Jacques Maritain: "We all agree on the rights, as long as no one asks us why." ${ }^{138}$ As discussed above, there is often a translation problem when it comes to discussions of human rights and humanitarian principles. There is also a problematic tendency to believe that only secular organizations are guided by human rights. Increased NGO capacity for such dialogue would bring greater depth and nuance to important humanitarian topics. In turn, such dialogue has the potential to reduce preconceptions and gaps in knowledge, allow for more relevant and rigorous capacity strengthening, and further promote local leadership.

- Examining the opportunities, risks, and deal-breakers around engagement with LFAs ${ }^{139}$ - and non-negotiable issues from the perspective of LFAs in their engagement with INGOs. ${ }^{140}$ When asked if engaging local religious actors would likely increase the organization's ability to work toward local humanitarian leadership, an Oxfam colleague answered, "It may, or it may not. But we need to ask ourselves that question in every humanitarian intervention." ${ }^{141}$ Toward this end, he said it is a matter of knowing "the right questions, not necessarily the answers." ${ }^{142}$ Another Oxfam colleague articulated the importance of generating metrics and quantitative data around engagement with LFAs. ${ }^{143}$ When it comes to "dealbreakers," it is important to distinguish between differences between INGOs and LFAs that would lead the INGO to decide that it could not work with the LFA on a particular project and disagreements that would lead the INGO to decide that it could not work with the LFA at all. ${ }^{144}$ Ager and Ager suggest that in some instances, the former approach-articulating disagreement with an LFA on a particular topic while remaining in partnership—may be the most effective way to bring about change. ${ }^{145}$

Finally, a critical step articulated by stakeholders is socializing the importance of engaging in religious literacy - the need to convince secular and faith-inspired INGOs that such training is important for our work. ${ }^{146}$ 


\section{ANALYSIS AND RECOMMENDATIONS}

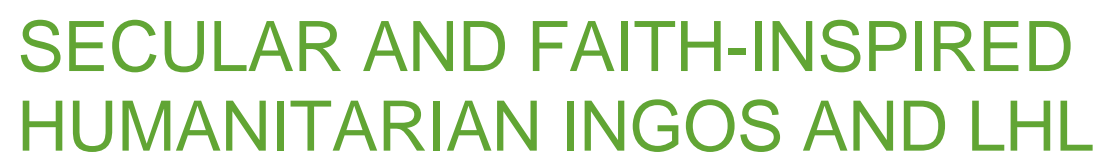

One impetus for Oxfam's interest in this research was curiosity about the imbalance of faithinspired humanitarian INGOs supporting local humanitarian leadership compared with their secular counterparts. Oxfam in the UK has been part of a consortium with Christian Aid, ActionAid, Tearfund, and CAFOD, conducting research on partnerships between local and international humanitarian actors-where FIOs are in the majority. A look at the signatories of the Charter for Change is similarly skewed toward FIOs. This scoping research was thus designed, in part, to ascertain if there is something particular to FIOs that leads them to embrace local humanitarian leadership, a difference in the LHL strategies or practices they employ, or in their effectiveness in working on LHL. Our research did not find any significant differences. The motivations of humanitarian INGOs working on LHL were what you would expect: both secular and faith-inspired humanitarian INGOs suggest that they are motivated largely by the effectiveness of LHL in most instances, and the FIOs also articulated a motivation stemming from their faith.

Even the FIO representatives who said they would like to think there was a difference in the effectiveness of their work on LHL could not offer evidence or even anecdotes of such. There were two significant differences in the strategy or practices of the LHL efforts of secular and faith-inspired humanitarian INGOs. One was the ready-made network of LFAs with whom faithinspired INGOs tend to partner (See discussion below). The other is the intermediary role that some faith-inspired INGOs play between donors and the UN, on the one hand, and LFAs on the other hand. It is not clear, however, if the finding was due to the fact that some of the FIOs interviewed were a smaller size than the secular INGOs interviewed, and it is often mediumsized INGOs that play the intermediary role. It also remains to be seen, in the research of Kathryn Kraft and others, whether and how the role of intermediaries fits into a global system moving toward local humanitarian leadership. ${ }^{147}$

In sum, it appears from this desk-based research focused on the INGO perspective that there is no reason to distinguish between the work of faith-inspired and secular humanitarian INGOs in the work to bring about local humanitarian leadership. These actors are already collaborating on advancing the LHL agenda in several ways, and should continue to do so, and they should continue to share learning with, and to learn lessons from, their colleagues, both secular and faith-inspired.

With respect to how faith-inspired and secular humanitarian INGOs think about and engage in local humanitarian leadership, we recommend the following:

- More in-depth research should be conducted to examine how all INGOs engage in LHL and to learn lessons for this work. It should consider whether the INGOs are playing a role as intermediary between LFAs and larger INGOs. This research should focus heavily on obtaining the perspectives of actors based in-country: field staff of INGOs and other actors and, particularly, local secular and faith actors. It could be structured as case studies focusing on a few INGOs in multiple locations-or multiple INGOs in one or two locations.

\section{PARTNERING WITH LOCAL FAITH ACTORS IN LHL WORK}

Our research suggests that the greatest difference in the "ways of working" of international secular and faith-based INGOs with respect to local humanitarian leadership is around their engagement with local faith actors. This scoping research suggests a difference in both the scale and nature of that engagement, which raises the question of the impact of such engagement. While all INGO representatives interviewed expressed a willingness to engage or 
work with local faith actors, almost all of the FIOs interviewed operate with a set network of LFAs in the countries where they work, and these are, by and large, the partners whose capacity they seek to strengthen, to whom they pledge to give a greater role in decision-making about joint work, and whose voice they endeavor to elevate in local, national, and global discussions. The secular INGOs interviewed, by contrast, may work from time to time with LFAs, but none identified any LFA that was an ongoing partner with whom they were engaging in work around local humanitarian leadership. ${ }^{148}$

There are important questions about the risks and opportunities of engaging with local faith actors in humanitarian action generally, and local humanitarian leadership efforts in particular. The plain truth is that religious leaders are often highly influential leaders of their communities (although see below for the related concern) and thus key leaders whom the international community should be supporting. The fact that it is local actors-and often local faith actorswho are generally first responders in a crisis makes the choice to invest in their leadership even more desirable, as does the tremendous voice LFAs have within their communities and, thus, the potential they have to affect social change on issues related to humanitarian crises and response. The lessons learned from not just the Ebola response, but the fight to end the stigma of HIVIAIDS, to raise awareness about the dangers of climate change, and to address gender equality are all powerful in this regard.

However, there are also very real concerns about, and risks related to, partnering with, and bolstering the leadership capacity and eventually the role of, LFAs in humanitarian assistance. Many LFAs, in particular religious institutions, are not set up to function like local or national NGOs: they do not have the infrastructure, their staff are not trained professionals in WASH, shelter, health, etc., and they may not be guided by the principles that largely guide humanitarian action. As a result, they may not be able to provide the same level of assistance as professional NGOs, they may not be able to scale up to take on a large project or absorb the associated funding, and they may not be in a position to do the above according to the humanitarian principles, particularly the principle of impartiality. Some LFAs may not be interested in being governed by such principles. Many of our interviewees, including ones representing faith-based INGOs, reported first-hand experience with partial delivery of assistance and proselytism by LFAs. On the other hand, many, many LFAs do adhere to the principles-which frequently mirror religious values, after all—and many are professional, highly skilled CBOs and NGOs that are providing high quality humanitarian assistance. The discussion around the humanitarian principles in particular is very convoluted and entrenched in neocolonialism and hypocrisy, ${ }^{149}$ yet it is also both a real and perceived concern, as some LFAs do deliver aid partially and engage in proselytizing - while some beneficiaries are reluctant or fearful of receiving aid from LFAs merely because of their connection to a particular (or any) religion.

Gender-including gender equality, gender-based violence (GBV), and other issues around the sexual and reproductive health of women and girls-is viewed by many as one of the primary sources of tension between secular and faith-inspired actors, although there is also a degree of hypocrisy and paternalism at play on this issue as well. ${ }^{150}$ But it is true that the typical religious leaders with which international actors partner are men and may not represent the entire community, particularly the most vulnerable. Finally, many researchers and LFAs in particular are concerned about the instrumentalization of LFAs by INGOs, which should be decreasing as local humanitarian leadership increases but will likely be slow to disappear given the power imbalances between the two sets of actors and the entrenched interests of INGOs to maintain that power.

With respect to the engagement by humanitarian INGOs with LFAs in local humanitarian leadership work, we recommend that:

- Further research should be conducted on the risks and opportunities of such engagement in LHL work. This research could be structured as standard case studies, focusing on a few locales, or it could be participatory action research (PAR), wherein individuals in the case study communities together with the researcher share in the ownership, analysis, and production of the research. ${ }^{151}$ The research should include, or be supplemented by, an examination of lessons learned from the development sector as well as from multilateral institutions and government aid agencies that engage with LFAs. ${ }^{152}$

- International practitioners (and LFAs) should give careful consideration to the "nonnegotiables," from their respective points of view, of engaging with each other-and whether 
a "deal-breaker"-e.g., over gender or impartiality—would preclude collaboration on that particular area of work or would preclude partnership generally.

- Practitioners and researchers should work together to prepare an analysis of the potential costs of not engaging with LFAs in LHL work.

- When engaging with local faith actors, INGOs should:

- Keep in mind that many LFAs are not primarily humanitarian actors. They are not smaller versions—clones or "mini-me's"- of the big INGOs, and they may have no interest in becoming such. Yet, while they may not have humanitarian experience or while their approaches to delivering assistance may differ from international humanitarian standards, they do have many assets to bring to bear, potentially including experience delivering social assistance to communities, capacity and expertise in other areas, networks, access, and clout within their communities. Both parties can certainly learn from each other.

- Not presume that religious leaders and LFAs represent everyone in their communities, particularly the most vulnerable. This is true even if the leaders are put forward by the government.

- Always look out for leadership outside the traditional hierarchies. While women are leaders in some faiths, they are often not part of the traditional hierarchy. In such instances they should be sought out, e.g., in women's faith groups.

- When discussing issues related to human rights and humanitarian principles, a) avoid jargon and speak in terms that are widely, and locally, understandable; b) do not presume that these values are universally held or interpreted the same by all; but also c) do not put on airs suggesting that international actors have the copyright on such values.

- Watch out for unintended instances where potential beneficiaries are reluctant to obtain assistance from an LFA because of a perception of partiality.

- Be aware of the risk of instrumentalizing LFAs, i.e., exploiting their capacity and resources by using them to accomplish the INGOs' goals, particularly when those goals vary from the LFAs'.

- Secular and faith-inspired humanitarian INGOs should consider joining initiatives such as the UN Interagency Taskforce on Religion and Development, ${ }^{153} \mathrm{JLI}$, and PaRD, ${ }^{154}$ and participating in conferences such as the upcoming October 2017 conference "Localizing Response to Humanitarian Need: The Role of Religious and Faith-Based Organizations." 155

\section{RELIGIOUS LITERACY}

When the former UN High Commissioner for Refugees— now UN Secretary General-António Guterres convened a dialogue on faith and protection in 2012, he noted "the need for humanitarian actors ... to deepen their understanding of religious traditions across faiths and to become more "faith literate." He went on to explain: "This means a better understanding not only of the central role of faith in the communities we work with, but more concretely of faith structures and networks, and of the different approaches needed for effectively engaging with different types of faith-based actors." 156

While our working hypothesis around different approaches to LHL by secular and faith-inspired humanitarian INGOs has not been born out by this scoping research, the findings around religious literacy were far richer and more exciting than anticipated. From the accounts of INGO representatives themselves and other key stakeholders, the answer about religious literacy was resounding: neither secular nor faith-based humanitarian INGOs have even a basic level of religious literacy, and while FIO staff may have a solid understanding of the beliefs, principles, and traditions of the religion that inspires the organization, they are no more advanced than their secular counterparts in other elements of religious literacy. Further, virtually all participants in the research, through interviews and the workshop, were firm in their belief that the ability of their organization (or INGOs generally, from other stakeholders) to continue to make progress toward LHL would benefit from a greater level of religious literacy-and we suspect that the few 
negative or ambivalent responses were the result of a misunderstanding about our broad interpretation of "religious literacy." It may be, of course, that interviews with field-based INGO staff would yield differing results, but we find these predominantly headquarters-focused interviews instructive.

When stakeholders identified aspects of religious literacy that they thought were most needed or would be most helpful in terms of furthering the LHL agenda, they named:

- Obtaining more information about relevant religious, cultural, and political factors in a given context;

- Developing "people-centric" approaches and metrics;

- Learning more about LFAs operating in the areas where INGOs are working;

- Allowing for religiously-based discussions of human rights and humanitarian principles;

- Recognizing secular assumptions and increasing organizational self-awareness; and

- Examining the advantages, disadvantages, opportunities, and deal-breakers around engagement with LFAs - and non-negotiable issues from the perspective of LFAs in their engagement with INGOs.

They also emphasized the critical need to socialize the very concept—and importance-of investing in religious literacy within their organizations and the whole humanitarian community.

With respect to INGOs investing in religious literacy in order to improve their humanitarian work generally and their local humanitarian leadership work in particular, we recommend:

- Practitioners and scholars should collaborate to create a religious literacy curriculum, or toolbox. It should:

- Be comprehensive, focusing not only on the key principles, beliefs, doctrine, and history of religions, but-more useful for an industry where people work in many different contexts-it will provide aid workers with the tools to gather this information, as well as key information about the relationship between religion, politics, and culture in a given context.

- Consider issues around gender and be intersectional.

- Reflect the internal diversity of many religions.

- Include discussions of "secular literacy."

- Be sufficiently flexible to meet the needs of various actors, including secular and faithbased INGOs.

- Both secular and faith-inspired humanitarian INGOs should examine and seek to address their own religious biases in their work on LHL as well as their other humanitarian work. Religious biases may include privileging particular religions or particular expressions of religion as more valid than others; they may include biases against secularism and secular worldviews. Secular biases may include a predisposition to considering religious spaces as unwelcoming and participating in religious spaces as a violation of their secularity. It is important to note that religious and secular biases may differ between headquarters and field offices, among field offices, and between national and international staff in field offices. 


\section{CONCLUSION}

This ambitious desk-based scoping research project examined a few large research questions involving complex and loaded terms and concepts: local humanitarian leadership, faith-inspired and faith-based, secular, local actors, impartiality and neutrality, and religious literacy. The research sought to gain insights into the assumptions, approaches, and ways of working on local humanitarian leadership, including with local faith actors, as well as the religious literacy of both secular and faith-inspired international humanitarian actors.

The most interesting findings were around engagement with local faith actors and religious literacy. On the former, the research was able to scratch the surface of the panoply of reasons that international humanitarian actors should partner with local faith actors, support their development, and work for them to have a bigger share of the leadership of humanitarian action in their country. We also saw the complexity of that engagement, given the fact that many LFAs are not humanitarian NGOs. These differences do not mean that engagement is impossible. In fact, the overall balance sheet appears in favor of engagement, but careful, thoughtful engagement that examines an organization's "non-negotiables" and weighs the cost of engaging with LFAs with the cost of not engaging with them. And, in every country, an INGO will need to conduct a context-specific analysis of a given LFA to determine if it is an organization with which the INGO wants to partner on a strategic basis, with a goal of working toward LHL.

This brings us to religious literacy. In order to navigate the waters of engaging with LFAs, humanitarian INGOs need greater religious literacy. This curriculum or toolbox should be created based on the broad understanding of the term used in this research: providing the tools needed for INGOs to 1) understand the role of religion and religious leaders in a given context; 2) identify the key LFAs in the community; 3) conduct a cost/benefit analysis of engaging with them; and 4) navigate that engagement.

In fact, we believe that a greater level of religious literacy would benefit humanitarian INGOs in all of their work, both in direct implementation, partnerships with local actors, and work to support and promote the capacity and leadership of such actors. Considering that eight in ten people worldwide identify with a religious group, ${ }^{157}$ and the role that religious institutions and organizations play in providing humanitarian assistance to people around the world, an understanding of these factors will only improve humanitarian assistance. 


\section{APPENDIX: INTERVIEWS AND CONSULTATIONS}

\section{Interviews conducted}

Alastair Ager, Director, Institute for Global Health and Development, Queen Margaret University, Edinburgh; Professor of Population and Family Health, Mailman School of Public Health, Columbia University

Mushida Akhter, Humanitarian Program Manager, Bangladesh, Oxfam

Sahar Ali, Humanitarian Program Manager, Sudan, Oxfam

Muhtari Aminu-Kano, Head of Research and Development, Islamic Relief Academy, Islamic Relief Worldwide

Nahuel Arenas-Garcia, Director of Humanitarian Programs and Policy, Oxfam America

Nobuyuki Asai, Program Coordinator, Soka Gakkai International

Chris Blackham, Head of Programs and Projects, Samaritan's Purse UK

Mark Brinkmoeller, Director, Center for Faith-Based and Community Initiatives, USAID

Elizabeth Cano, Humanitarian Coordinator, Peru, Oxfam

Oenone Chadburn, Head of Humanitarian Support, Tearfund

Elena Fiddian-Qasmiyeh, Reader in Human Geography and Co-Director, Migration Research Unit, University College London

Juliano Fiori, Humanitarian Affairs Advisor, Save the Children UK

Enrique Garcia, Regional Humanitarian Coordinator, Latin America and the Caribbean, Oxfam

Nigel Harris, Chief Executive Officer, Tearfund

Jessica J. Jordan, OCHA Yemen, Amman Hub

Azza Karam, Senior Advisor on Culture and Social Development, UN Population Fund (UNFPA); Coordinator, UN Inter-Agency Task Force on Religions \& Development

Lex Kassenberg, Emergency \& Humanitarian Director, Care USA

Anwar Khan, Chief Executive Officer, Islamic Relief USA

Bob Kitchen, Emergency Director, International Rescue Committee

Kathryn Kraft, Lecturer in International Development, University of East London

Kate Latimir, Gender and Protection Specialist, British Red Cross

Jemilah Mahmood, Under Secretary General for Partnerships, International Federation of the Red Cross and Red Crescent Societies (IFRC) (Founder and former Director, Mercy Malaysia)

Katherine Marshall, Senior Fellow, Berkley Center for Religion, Peace and World Affairs and Professor of the Practice of Development, Religion, and Conflict in the School of Foreign Service, Georgetown University; Executive Director, World Faiths Development Dialogue

Ruth Messinger, Global Ambassador (formerly President and CEO), American Jewish World Service

Haissam Minkara, Deputy Country Director, Iraq, Oxfam 
Amjad Mohamed-Saleem, Political Analyst, NEAR Network

Katherine Nightingale, Head of Advocacy and Policy, Care International UK, speaking in her personal capacity

Dean Pallant, Under Secretary for Programme Resources and International Health Services Coordinator, The Salvation Army International

Jennifer Poidatz, Humanitarian Director, Catholic Relief Services

Gregory Ramm, Vice President, Policy and Humanitarian Response, Save the Children US

José Riera-Cézanne, retired (formerly Special Adviser to the Director, UN High Commission for Refugees)

Adam Russell Taylor, Lead, Faith Initiative, World Bank

Mark Smith, Senior Director, Humanitarian and Emergency Affairs, World Vision

Father Thomas Smolich, SJ, International Director, Jesuit Refugee Service

Nigel Timmins, Humanitarian Director, Oxfam

Paul Valentin, International Director, Christian Aid

Mark Webster, Chief Executive Officer, Adventist Development and Relief Agency (ADRA) Australia

\section{Additional people consulted}

Vinya Ariyaratne, General Secretary, Sarvodaya Shramadana Movement

Judy Beals, Director, Private Sector Department, Oxfam

Rudelmar Bueno de Faria, World Council of Churches Representative to the United Nations;

Coordinator of UN Ecumenical Office, New York

Jean Duff, Director, Partnership for Faith \& Development; Coordinator, Joint Learning Initiative on Faith \& Local Communities

Matthew Frost, Chair of Board, Joint Learning Initiative on Faith \& Local Communities (formerly CEO, Tearfund)

Fadi Hallisso, CEO and Co-founder, Basmeh and Zeitooneh

Brie Loskota, Executive Director, Center for Religion and Civic Culture, University of Southern California

Manal Omar, Associate Vice President for the Middle East and Africa Center, US Institute of Peace

Olivia Wilkinson, PhD, Trinity College, Dublin

Tahir Zaman, Visiting Research Fellow, Centre for Religion, Conflict and the Public Domain, University of Groningen 


\section{BIBLIOGRAPHY}

Abdulaziz, Sharifa, Omayma El Ella, Elena Fiddian-Qasmiyeh, Ellen Hansen, Elisabet Le Roux, Marie-Claude Poirier, José Riera-Cézanne, Helen Stawski, Olivia Wilkinson, and Erin K. Wilson. Gender, Religion and Humanitarian Responses to Refugees. Edited by Elena FiddianQasmiyeh. UCL Migration Research Unit - Policy Brief. UCL, 2016.

http://jliflc.com/resources/gender-religion-humanitarian-responses-refugees/.

Ager, Alastair, and Joey Ager. Faith, Secularism, and Humanitarian Engagement: Finding the Place of Religion in the Support of Displaced Communities. New York: Palgrave Macmillan, 2015. https://doi.org/10.1057/9781137472144

Ager, Joey, Elena Fiddian-Qasmiyeh, and Alastair Ager. "Local Faith Communities and the Promotion of Resilience in Contexts of Humanitarian Crisis." Journal of Refugee Studies 28, no. 2 (June 1, 2015): 202-21. https://doi.org/10.1093/jrs/fev001

Banchoff, Thomas, ed. Religious Pluralism, Globalization, and World Politics. New York: Oxford University Press, 2008.

Barnett, Michael. "Where is the Religion? Humanitarianism, Faith, and World Affairs." In Rethinking Religion and World Affairs, edited by Timothy Samuel Shah, Alfred Stepan, and Monica Duffy Toft, 165-181. New York: Oxford University Press, 2012. https://doi.org/10.1093/acprof:oso/9780199827978.003.0011

Barnett, Michael N., and Janice Gross Stein. Sacred Aid: Faith and Humanitarianism. New York: Oxford University Press, 2012. https://doi.org/10.1093/acprof:oso/9780199916023.001.0001

Barnett, Michael, and Peter Walker, "Regime Change for Humanitarian Aid: How to Make Relief More Accountable," Foreign Affairs (July/August 2015): 130-141.

Benedetti, Carlo. "Islamic and Christian Inspired Relief NGOs: Between Tactical Collaboration and Strategic Diffidence?" Journal of International Development 18, no. 6 (August 2006): 84959. https://doi.org/10.1002/jid.1318

Benthall, Jonathan. '“Cultural Proximity' and the Conjuncture of Islam with Modern Humanitarianism." In Sacred Aid: Faith and Humanitarianism, edited by Michael N. Barnett and Janice Gross Stein, 65-89. New York: Oxford University Press, 2012. https://doi.org/10.1093/acprof:oso/9780199916023.003.0003

Berger, Julia. "Religious Nongovernmental Organizations: An Exploratory Analysis." Voluntas: International Journal of Voluntary and Nonprofit Organizations 14, no. 1 (March 2003): 15-39. https://doi.org/10.1023/A:1022988804887

Brikci, Nouria. "Is Cultural Proximity the Answer to Gaining Access in Muslim Contexts?" Humanitarian Exchange Magazine, March 2005. http://odihpn.org/magazine/is-culturalproximity-the-answer-to-gaining-access-in-muslim-contexts.

Butler, Judith, Jurgen Habermas, Charles Taylor, Cornel West. The Power of Religion in the Public Sphere. Edited by Eduardo Mendieta and Jonathan VanAntwerpen. New York: Columbia University Press, 2011.

Carrette, Jeremy, and Sophie-Hélèn Trigeaud. "The Religion-Secular in International Politics: The Case of Religious NGOs at the United Nations in Social Identities Between the Sacred and the Secular." In Social Identities between the Sacred and the Secular. Ashgate AHRC/ESRC Religion and Society Series. Edited by Abby Day, Giselle Vincent, and Christopher R. Cotter. Abingdon, UK and New York: Routledge, 2013.

Casanova, José. "The Secular and Secularisms." Social Research 76, no. 4 (Winter 2009): 1049-66.

Cheema, Abdur Rehman, Regina Scheyvens, Bruce Glavovic, and Muhammad Imran. "Unnoticed but important: revealing the hidden contribution of community-based religious institution of the mosque in disasters." Natural Hazards 71, no. 3 (April 2014): 2207-29. 
http://link.springer.com/article/10.1007/s11069-013-1008-0. https://doi.org/10.1007/s11069013-1008-0

Clarke, Gerard, and Michael Jennings, eds. Development, Civil Society and Faith-Based Organizations: Bridging the Sacred and the Secular. International Political Economy Series. Houndmills, England and New York: Palgrave Macmillan, 2008.

https://doi.org/10.1057/9780230371262

De Cordier, Bruno. "Faith-Based Aid, Globalisation and the Humanitarian Frontline: An Analysis of Western-Based Muslim Aid Organisations." Disasters 33, no. 4 (October 2009): 608-28. https://doi.org/10.1111/j.1467-7717.2008.01090.x

"On the Thin Line Between Good Intentions and Creating Tensions: A View on Gender Programmes in Muslim Contexts and the (Potential) Position of Islamic Aid Organisations." European Journal of Development Research 22, no. 2 (April 2010): 234-51. https://doi.org/10.1057/ejdr.2010.2

Ferris, Elizabeth. "Faith and Humanitarianism: It's Complicated." Journal of Refugee Studies 24, no. 3 (2011): 606-25. http://studylib.net/doc/18684202/journal-of-refugee-studies-2011-ferris606-25. https://doi.org/10.1093/jrs/fer028

"Faith-Based and Secular Humanitarian Organizations." International Review of the Red Cross 87, no. 858 (June 2005): 311-25.

https://www.icrc.org/eng/assets/files/other/irrc_858_ferris.pdf. https://doi.org/10.1017/S1816383100181366

Fiddian-Qasmiyeh, Elena. "Introduction: Faith-Based Humanitarianism in Contexts of Forced Displacement." Journal of Refugee Studies 24, no. 3 (September 2011): 429-39.

https://doi.org/10.1093/jrs/fer033

"The Pragmatics of Performance: Putting 'Faith' in Aid in the Sahrawi Refugee Camps." Journal of Refugee Studies 24, no. 3 (September 2011): 533-47. https://doi.org/10.1093/jrs/fer027

Fiddian-Qasmiyeh, Elena, and Alastair Ager, eds. Local faith communities and the promotion of resilience in humanitarian situations: a scoping study. Working Paper Series 90. Oxford: Refugee Studies Centre and Joint Learning Initiative on Faith \& Local Communities, February 2013. https://www.rsc.ox.ac.uk/files/publications/working-paper-series/wp90-local-faithcommunities-resilience-2013.pdf.

Ghandour, Abdel-Rahman. Jihad humanitaire: enquête sur les ONG islamiques. Paris: Flammarion, 2002.

Gingerich, Tara R., and Marc J. Cohen. Turning the Humanitarian System on Its Head. Oxfam Research Reports. Oxford: Oxfam, July 2015.

https://www.oxfam.org/sites/www.oxfam.org/files/file_attachments/rr-turning-humanitariansystem-local-capacity-270715-en.pdf.

Haynes, Jeffrey. Faith-Based Organizations at the United Nations. Palgrave Studies in Religion, Politics, and Policy. New York: Palgrave Macmillan, 2014.

https://doi.org/10.1057/9781137404510

Humanitarian Policy Group. Time to let go: Remaking humanitarian action for the modern era. London: Oversees Development Institute, April 2016. https://www.odi.org/publications/10381time-let-go-remaking-humanitarian-action-modern-era.

International Partnership on Religion and Sustainable Development. Religious Engagement in Humanitarian Crisis: Good Practice Collection. 2016. http://jiflc.com/resources/religiousengagement-humanitarian-crises-good-practice-collection/.

Joint Learning Initiative on Faith \& Local Communities. Building More Effective Partnerships between the Public Sector and Faith Groups. 2015.

https://jliflc.com/wpcontent/uploads/2015/06/NEWBuilding-more-effective-partnerships-betweenpublic-sector-and-faith-groups-1.pdf. 
Karam, Azza. Realizing the Faith Dividend: Religion, Gender, Peace and Security in Agenda 2030. United Nations Population Fund, 2016. https://www.unfpa.org/sites/default/files/pubpdf/50426_UNFPA_Donor-UN-FBO-Consultations_Web.pdf

Kawanami, Hiroko, and Geoffrey Samuel, eds. Buddhism, International Relief Work, and Civil Society. New York: Springer, 2013.

Khan, Ajaz Ahmed, Ismayil Tahmazov, and Mamoun Abuarqub. Translating Faith into Development. Islamic Relief Worldwide: June 2009. http://chede.org/chede/wpcontent/uploads/2011/08/Translating-Faith-into-Development-Islamic-tradition.pdf.

Krafess, Jamal. "The Influence of the Muslim Religion in Humanitarian Aid." International Review of the Red Cross 87, no. 858 (2005): 327-42.

https://www.icrc.org/eng/assets/files/other/irrc_858_krafess.pdf.

https://doi.org/10.1017/S1816383100181378

Kraft, Kathryn. "Faith and impartiality in humanitarian response: Lessons from Lebanese evangelical churches providing food aid." International Review of the Red Cross 97, no. 897-98 (June 2015): 395-421. https://www.icrc.org/en/download/file/19020/irc_97_1-2-16.pdf.

Kraft, Kathryn, and Suzanne Manar. Hope for the Middle East: The Impact and Significance of the Christian Presence in Syria and Iraq: past, present, and future. Open Doors, Served, University of East London, and Middle East Concern, February 2016. http://www.opendoorsuk.org/campaign/documents/H4ME-report.pdf.

Lehmann, Karsten. Religious NGOs in International Relations: The Construction of 'the Religious' and 'the Secular'. Routledge Studies in Religion and Politics. Abingdon, UK and New York: Routledge, 2016.

"Shifting Boundaries Between the Religious and the Secular: Religious Organizations in Global Public Space." Journal of Religion in Europe 6, no. 2 (2013): 201-28. https://doi.org/10.1163/18748929-00602004

Marshall, Katherine. "Faith, Gender, and International Affairs." In Sacred Aid: Faith and Humanitarianism, edited by Michael N. Barnett and Janice Gross Stein, 182-92. New York: Oxford University Press, 2012. https://doi.org/10.1093/acprof:oso/9780199827978.003.0012

- Global Institutions of Religion: Ancient Movers, Modern Shakers. Global Institutions Series 75. London and New York: Routledge, 2013.

Responding to the Ebola Epidemic in West Africa: What Role Does Religion Play? Berkley Center for Religion, Peace, and World Affairs at Georgetown University and World Faiths Development Dialogue, May 2016.

https://berkleycenter.georgetown.edu/publications/responding-to-the-ebola-epidemic-in-westafrica-what-role-does-religion-play.

Mohamed, Abdulfatah Said, and Ronald Ofteringer. "'Rahmatan lil-'alamin' (A mercy to all creation): Islamic voices in the debate on humanitarian principles." International Review of the Red Cross 97, no. 897-98 (2016): 371-94.

https://www.icrc.org/en/download/file/19017/irc_97_1-2-15.pdf.

Moore, Diane L. Methodological Assumptions and Analytical Frameworks Regarding Religion. Religious Literacy Project: (2016).

"Overcoming Religious Illiteracy: A Cultural Studies Approach." World History Connected 4, no. 1 (November 2006). http://worldhistoryconnected.press.illinois.edu/4.1/moore.html.

Palmer, Victoria. "Analysing Cultural Proximity: Islamic Relief Worldwide and Rohingya Refugees in Bangladesh." Development in Practice 21, no. 1 (2011): 96-108.

https://doi.org/10.1080/09614524.2011.530226

Petersen, Marie Juul. "International Religious NGOs at The United Nations: A Study of a Group of Religious Organizations." The Journal of Humanitarian Assistance (November 17, 2010). https://sites.tufts.edu/jha/archives/847. 
Ratcliffe, John. "Local Islamic Response to the 2004 Indian Ocean Tsunami and 2005 Kashmir Earthquake." In Understanding Islamic Charities, edited by Jon B. Alterman and Karin Von Hippel. Washington, DC: CSIS Press, 2007.

Says, Mehmet Ozay. "Have Islamic Aid Agencies a Privileged Relationship in Majority Muslim Areas? The Case of Post-Tsunami Reconstruction in Aceh." The Journal of Humanitarian Assistance (June 26, 2008). https://sites.tufts.edu/jha/archives/153.

Shah, Timothy Samuel, Alfred Stepan, and Monica Duffy Toft, eds. Rethinking Religion and World Affairs. New York: Oxford University Press, 2012.

Thomas, Scott M. The Global Resurgence of Religion and the Transformation of International Relations: The Struggle for the Soul of the Twenty-First Century. Culture and Religion in International Relations. New York: Palgrave Macmillan, 2005.

https://doi.org/10.1057/9781403973993

Various. "Faith and Responses to Displacement." Forced Migration Review no. 48 (November 2014). http://www.fmreview.org/faith.html.

Wilkinson, Olivia. Faith and Resilience after Disaster: The Case of Typhoon Haiyan. Misean Cara, November 2015. http://www.miseancara.ie/wp-content/uploads/2016/02/Faith-ResilienceAfter-Disaster.pdf.

Wilkinson, Olivia, Alastair Ager, Tim Ingram, David Boan, and Nobuyuki Asai. Engaging local faith communities for sustainable capacity for prevention and response. Joint Learning Initiative on Faith \& Local Communities Evidence Brief 4 for the World Humanitarian Summit. JLI, May 2016. https://jiflc.com/wp/wp-content/uploads/2016/05/WHS_JLIFLC_Evidence-Brief_4-

ONLINE-1.pdf. 
1 We use the terms "natural disasters," in quotation marks, or "disasters from natural hazards" because hazards such as earthquakes and droughts are natural occurrences, but the disasters that often follow them (death, damage, etc.) are the direct result of human activity and public policies (e.g., failure to adopt and enforce building codes). It is for this reason that the damage caused by natural hazards varies so widely but is largely correlated to the level of poverty in a given community. See, e.g., Tanja SchuemerCross and Ben Heaven Taylor, The Right to Survive: The humanitarian challenge for the twenty-first century (Oxfam, 2009); United Nations and World Bank, Natural Hazards, Unnatural Disasters: The Economics of Effective Prevention (Washington: World Bank, 2010).

2 In some electric train systems, the third rail carries the electric current and thus poses a risk of electrocution.

3 Issues of personal faith and the types of assistance provided by humanitarian actors are beyond the scope of this research, except insofar as they relate to local leadership.

4 See, e.g., Alastair Ager and Joey Ager, Faith, Secularism, and Humanitarian Engagement: Finding the Place of Religion in the Support of Displaced Communities (New York: Palgrave Macmillan, 2015); Joey Ager, Elena Fiddian-Qasmiyeh, and Alastair Ager, "Local Faith Communities and the Promotion of Resilience in Contexts of Humanitarian Crisis," Journal of Refugee Studies 28, no. 2 (June 1, 2015); Michael Barnett, "Where is the Religion? Humanitarianism, Faith, and World Affairs," in Rethinking Religion and World Affairs, ed. Timothy Samuel Shah, Alfred Stepan, and Monica Duffy Toft, 165-81 (New York: Oxford University Press, 2012); Elizabeth Ferris, "Faith and Humanitarianism: It's Complicated," Journal of Refugee Studies 24, no. 3 (2011): 606-25; Elena Fiddian-Qasmiyeh, "The Pragmatics of Performance: Putting 'Faith' in Aid in the Sahrawi Refugee Camps," Journal of Refugee Studies 24, no. 3 (September 2011): 429-39.

5 Previously open only to UN agencies, the UN taskforce now welcomes INGOs as members.

6 The conference is being organized by a large number of FBOs and JLI. "Localizing Response to Humanitarian Need: The Role of Religious and Faith-Based Organizations," http://pfaithdev.weebly.com/localizing-response-to-humanitarian-need.html.

7 Tara R. Gingerich and Marc J. Cohen, Turning the Humanitarian System on Its Head: Saving Lives and Livelihoods by Strengthening Local Capacity and Shifting Leadership to Local Actors, Oxfam Research Reports (Oxford: Oxfam, July 2015), https://www.oxfam.org/en/research/turning-humanitarian-system-itshead. See also ALNAP, The State of the Humanitarian System (London: ALNAP, 2015), http://sohs.alnap.org; Sophia Swithern et al., Global Humanitarian Assistance Report 2015 (Bristol, UK: Global Humanitarian Assistance, Development Initiatives, 2015),

http://www.globalhumanitarianassistance.org/wp-content/uploads/2015/06/GHA-Report-2015_Interactive Online.pdf; Humanitarian Policy Group, Time to let go: Remaking humanitarian action for the modern erā (London: Overseas Development Institute, April 2016), https://www.odi.org/publications/10381time-let-go-remaking-humanitarian-action-modern-era.

8 Elena Fiddian-Qasmiyah, South-South Educational Migration, Humanitarianism and Development: Views from Cuba, North Africa and the Middle East, Routledge Studies in Development, Mobilities and Migration (Oxford: Routledge, January 2015), 22.

9 Intergovernmental Panel on Climate Change, "Summary for Policymakers," in Climate Change 2014: Impacts, Adaptation, and Vulnerability, Part A: Global and Sectoral Aspects; Contribution of Working Group II to the Fifth Assessment Report of the Intergovernmental Panel on Climate Change, ed. Christopher B. Field et al. (New York: Cambridge University Press, 2014), 11-13.

10 For Oxfam, this means a belief "that respect for human rights will help lift people out of poverty and injustice, allow them to assert their dignity and guarantee sustainable development" and a belief that people should have the right to a livelihood, basic services, to be safe from harm, to be heard, and to be treated as equal. See https://www.oxfam.org/en/our-commitment-human-rights. It also means being guided by the legal standards found in the range of international human rights treaties and conventions. See Oxfam, Quick Guide to Rights-Based Approaches to Development (Oxfam, 2014), http://oxfamilibrary.openrepository.com/oxfam/bitstream/10546/312421/1/ml-quick-guide-to-rba-300114en.pdf.

11 One of the most promising tangible outcomes has been the Grand Bargain, a package of reforms around humanitarian financing. "The Grand Bargain-A Shared Commitment to Better Serve People in Need" (2016), http://www.agendaforhumanity.org/initiatives/3861.

12 As one INGO representative admitted, "Even though we have been working for a long time with local partners, the issue lies in the word 'partner.' What is the definition of a 'partner'? We realized that even though we were talking about local NGOs as 'partners' for a long time, effectively what we were doing is using local partners as contractors to implement our activities." 
13 Charter for Change, https://charter4change.org. The Charter for Change sets out a series of eight commitments by humanitarian INGOs around LHL to which INGOs pledge to achieve by May 2018. There are 29 INGO signatories.

14 See, e.g., Lydia Poole, Funding at the Sharp End: Investing in National NGO Response Capacity (London: Catholic Agency for Overseas Development, 2013); Katherine Nightingale, Building the Future of Humanitarian Aid: Local Capacity and Partnerships in Emergency Assistance (London: Christian Aid, 2012); Ben Ramalingam, Bill Gray, and Giorgia Cerruti, Missed Opportunities: The Case for Strengthening National and Local Partnership-based Humanitarian Responses (London: Christian Aid, CAFOD, Oxfam, Tearfund, and ActionAid, 2013); Andy Featherstone, Missed Again: Making space for partnership in the Typhoon Haiyan Response (London: Christian Aid, CAFOD, Oxfam, Tearfund, and ActionAid, 2014).

15 Gingerich and Cohen, Turning the Humanitarian System, 14 (citing Development Initiatives, Global Humanitarian Assistance 2014 (Bristol, UK: Development Initiatives, 2014)). From 2007-2013 only 1.87 percent of global humanitarian assistance went directly to LNHAs. Ibid. In 2012, for instance, 61 percent of global reported funding went to multilateral agencies and 17 percent to INGOs, while 0.4 percent went to local and national NGOs. Ibid.

16 With each pass-through, fewer funds get passed on for the implementation of a project. Also, it should be noted that, while INGOs always keep a portion of the funds for their overhead expenses, they rarely allow LNHAs any overhead expenses or "core funding," which is essential to building the organizational capacity and sustainability of an organization.

17 See, e.g., Michael Barnett and Peter Walker, "Regime Change for Humanitarian Aid: How to Make Relief More Accountable," Foreign Affairs (July/August 2015): 135; Peter Walker, "Locally-led humanitarian aid," TEDxLakeGeneva, May 14, 2014, https://www.youtube.com/watch?v=vCGjRIVdOpc.

18 Pew Research Center, "Religiosity," in Unfavorable Views of Jews and Muslims on the Increase in Europe (September 2008), http://www.pewglobal.org/2008/09/17/chapter-2-religiosity/.

19 Kathryn Kraft, interview, December 2016.

20 For example, Cheema et al. examine the distinctive and multifaceted role of mosques' disaster management following the 2005 earthquake in Pakistan. Abdur Rehman Cheema, Regina Scheyvens, Bruce Glavovic, and Muhammad Imran, "Unnoticed but important: revealing the hidden contribution of community-based religious institution of the mosque in disasters," Natural Hazards 71, no. 3 (April, 2014): 2207-29.

21 Matthew Duss, Yasmine Taeb, Ken Gude, and Ken Sofer, Fear Inc. 2.0: The Islamophobia Network's Efforts to Manufacture Hate in America (Washington, DC: Center for American Progress, February 2015), https://www.americanprogress.org/issues/religion/reports/2015/02/11/106394/fear-inc-2-0/.

22 There is significant literature examining the relationship between religious engagement in humanitarian action and effective humanitarian action, and significant literature examining the relationship between LHL and effective humanitarian action, but little focused on the relationship between religious engagement in humanitarian action and LHL.

23 A problem-centered interview methodology means that both participants are focused on ultimately establishing the respondent's perspective on a key area of concern outlined at the beginning by the interviewer. Andreas Witzel and Herwig Reiter, The Problem-Centered Interview: Principles and Practice (London: SAGE Publications Ltd., 2012), http://methods.sagepub.com/book/the-problem-centred-interview.

24 Whenever possible, we avoided introducing contentious terms to the discussion, allowing respondents to introduce and define their own terms. When we did use contentious terms, we articulated our definition.

25 Diane L. Moore, "Overcoming Religious Illiteracy: A Cultural Studies Approach," World History Connected 4, no. 1 (November 2006), http://worldhistoryconnected.press.illinois.edu/4.1/moore.html. See also Diane L. Moore, "Definition of Religious Literacy," Religious Literacy Project website, http://rlp.hds.harvard.edu/definition-religious-literacy.

26 The definition of "local actor" is currently being debated at the global level, as the Grand Bargain on reforms around humanitarian financing stemming from the World Humanitarian Summit includes commitments on funding to local actors. In order to track such funding, efforts are underway to create a "localization marker."

27 The concept of "faith-based" has a different connotation within Muslim organizations, which are more disconnected from specific religious institutions (mosques) and leaders.

28 Katherine Marshall, Global Institutions of Religion: Ancient Movers, Modern Shakers, Global Institutions Series 75 (London and New York: Routledge, 2013), 5.

29 For a review of academic discourse on the use of "secular" and related terms, see José Casanova, "The Secular and Secularisms," Social Research 76, no. 4 (Winter 2009): 1049-66. On the difficulties of the use of "religion" and "secular" in the UN-led NGO system, see Jeremy Carrette and Sophie-Hélèn Trigeaud, "The Religion-Secular in International Politics: The Case of Religious NGOs at the United Nations in Social Identities Between the Sacred and the Secular," in Social Identities between the Sacred and the Secular, ed. Abby Day, Giselle Vincent, and Christopher R. Cotter (Abingdon, UK and New York: Routledge, 2013). 
30 Sharifa Abdulaziz et al., Gender, Religion and Humanitarian Responses to Refugees, ed. Elena Fiddian-Qasmiyeh (UCL Migration Research Unit, 2016), 6, www.geog.ucl.ac.uk/research/researchcentres/migration-research-unit. See also Alastair and Joey Ager's discussion of secularism, and of Charles Taylor's writing on secularism, in Ager and Ager, Faith, Secularism, and Humanitarian Engagement, 8-11.

31 These concepts are related but not the same. LHL is not solely about working with or through partners. Partnerships between local and international actors are almost always uneven in terms of power and often look more like subcontractor relationships than actual partnerships built on trust and respect. Also, it is one thing to support working in or through partnerships and another to believe that local actors should be "calling the shots" in their countries. That said, organizations that tend to work primarily or exclusively through local actors often do view those actors as true partners and seek and value their input on everything-not only on implementation, but also on needs assessment, program design, and monitoring, evaluation, and learning.

32 Médecins Sans Frontières (MSF), the Norwegian Refugee Council, and the International Rescue Committee are among these organizations. See, e.g., Ed Schenkenberg, The Challenges of Localised Humanitarian Aid in Armed Conflict (MSF, November 2016), https://emergencygap.msf.es/papers/emergency-gap-challenges-localised-humanitarian-aid.

It should be noted that most, if not all, organizations that support LHL believe that it is often but not always the best practice.

33 See, e.g., Schenkenberg, The Challenges of Localised Humanitarian Aid, 20.

34 See, e.g., Jessica Jordan, interview, January 2017 ("At the ground level, I cannot point to anything where I think they're doing anything [in terms of their work on LHL] differently. On the contrary, I think they all do great work"); Lex Kassenberg, interview, February 2017; Katherine Nightingale, interview, December 2016; Alastair Ager, remarks, Harvard/Oxfam workshop, Cambridge, MA, January 2017; Fadi Halleiso, remarks, Harvard/Oxfam workshop, Cambridge, MA, January 2017.

35 See, e.g., Elena Fiddian-Qasmiyeh and Alastair Ager, eds., Local Faith Communities and the promotion of resilience in humanitarian situations: A scoping study, JLI and Refugee Studies Centre Working Paper 90 (Oxford: Refugee Studies Centre, February 2013).

36 Anwar Khan, interview, November 2016; Jennifer Poidatz, interview, November 2016; Mark Smith, interview, January 2017; Muhtari Aminu-Kano, interview, December 2016. See also JLI, Building More Effective Partnerships between the Public Sector and Faith Groups (2015), 10, https://jliflc.com/wpcontent/uploads/2015/06/NEWBuilding-more-effective-partnerships-between-public-sector-and-faithgroups-1.pdf.

37 In Kraft's research, intermediary chains for faith-based humanitarian actors may actually be as many as five layers deep. From bottom to top, there would be a local religious institution or CSO supported by a local FIO. That local FIO would be supported by a middle-sized INGO, which may be supported by an even larger INGO. Finally, the INGOs are supported by a funding network. In collaboration with Jonathan D. Smith, Kraft's published study of these findings is forthcoming.

38 It should be noted that FIO interviewees included many more middle-sized NGOs whereas the secular NGO interviewees were larger. Thus, this potential finding could have more to do with size than religious affiliation and requires further examination.

39 Kraft, interview.

40 Nightingale, interview.

41 See Jonathan Benthall, "'Cultural Proximity' and the Conjuncture of Islam with Modern Humanitarianism," in Sacred Aid: Faith and Humanitarianism, eds. Michael N. Barnett and Janice Gross Stein 65-89 (New York: Oxford University Press, 2012), 66; Fiddian-Qasmiyeh and Ager, Local Faith Communities.

When respondents were asked whether they have witnessed or otherwise directly heard of operational advantages based on the faith association of a humanitarian NGO, their answers ranged from "absolutely" to "probably, depending on the context," and many had anecdotal stories to share. Amjad MohamedSaleem, interview, January 2017; Khan, interview; Bob Kitchen, interview, November 2016; Chris Blackham, interview, December 2016; Mark Brinkmoeller, interview, December 2016; Mark Webster, interview, December 2016. See also Qasmiyeh and Ager, Local Faith Communities. Interestingly, multiple FIO respondents claimed that these advantages often moved across religious boundaries (e.g., to Christian organizations in Muslim-majority countries and vice versa). In other words, the decisive factor for the operational advantage that FIOs believe they have did not seem to be that they had the same religious or doctrinal beliefs as local beneficiaries. While respondents did give credit to cultural proximity in the sense that sharing a basic faith perspective provided some operational advantages, they emphasized a second explanation as well: the ability and willingness to allow for faith-based dialogue and reasoning on issues of local importance. Khan, interview; Blackham, interview; Nigel Harris and Oenone Chadburn, interview, January 2017; Paul Valentin, interview, December 2016.

Of course, there are also contexts where faith-inspired humanitarian actors are at a disadvantage. In some conflicts where religion is a significant factor, countries where a religious group has become marginalized, 
and areas where religious categories have strong political connotations, the affiliation with faith may hinder the work of FIOs. Valentin, interview; Blackham, interview; Khan, interview; Haissam Minkara, interview, January 2017; Katherine Marshall, interview, November 2016.

42 A power analysis is an examination of the current distribution of power among different actors (i.e., the dynamics of power) and the dimensions where power operates. It is part of a context analysis.

43 See, e.g., Ferris, "Faith and Humanitarianism."

44 Blackham, interview; Harris and Chadburn, interview; Khan, interview; Aminu-Kano, interview; Webster, interview.

IR, for example, has a strong contractual relationship with Lutheran World Foundation. See

https://www.lutheranworld.org/news/lwf-and-Islamic-relief-sign-memorandum-understanding.

45 Blackham, interview. See also Qasmiyeh and Ager, Local Faith Communities.

46 Blackham, interview.

47 Nahuel Arenas, interview, November 2016.

48 Greg Ramm, interview, December 2016.

49 Azza Karam, interview, December 2016; Jemilah Mahmood, interview, December 2016; Nobuyuki Asai, interview, December 2016. See also Elizabeth Ferris, "Faith-based and secular humanitarian organizations," International Review of the Red Cross 87, no. 858 (June 2005), https://www.icrc.org/eng/assets/files/other/irrc_858_ferris.pdf.

Of course, this is not true across the board, and in many countries the civil society space of LFAs of minority religions in particular is severely constrained.

50 Poidatz, interview; José Riera-Cézanne, interview, January 2017; Kraft, interview; Minkara, interview.

51 Poidatz, interview. Speaking about religious orders, Poidatz also said, "It's not like [secular INGOs] would interact with them in their day-to-day functioning." Ibid.

52 Riera-Cézanne, interview.

53 Blackham, interview; Brinkmoeller, interview; Harris and Chadburn, interview; Smith, interview.

Christian Aid, CAFOD, Tearfund, and IR Worldwide produced a report on this topic. See Andy

Featherstone, Keeping the Faith: The Role of Faith Leaders in the Ebola Response (Christian Aid, CAFOD, Tearfund, Islamic Relief Worlwide, July 2015). See also Katherine Marshall, Responding to the Ebola Epidemic in West Africa: What Role Does Religion Play? (Berkley Center for Religion, Peace, and World Affairs at Georgetown University and World Faiths Development Dialogue, May 2016), https://berkleycenter.georgetown.edu/publications/responding-to-the-ebola-epidemic-in-west-africa-whatrole-does-religion-play.

54 Adam Russell Taylor, interview, December 2016 (example of pastors and imams getting people to use bed nets to combat malaria when they were not being used for cultural reasons); Webster, interview, January 2017 (engaging with religious leaders to develop "a theology of gender equality"); Murshida Ahkter, interview, February 2017 (religious leaders in Bangladesh saying it is OK for women to leave their homes without permission of their husbands, as is typically required, to go to an emergency shelter in a cyclone); Nigel Timmins, interview, February 2017 (working on early marriage in Yemen, where a group of imams recommended changing the law); Valentin, interview (HIVIAIDS and climate change). See also Abdulaziz et al., Gender, Religion and Humanitarian Responses, 6; JLI, Building More Effective Partnerships, 6.

55 Harris and Chadburn, interview; Valentin, interview; Webster, interview; Aminu-Kano, interview

56 Aminu-Kano, interview.

57 Minkara, interview.

58 Judy Beals, email message to author, February 2017.

59 Arenas, interview.

60 Abdulaziz et al., Gender, Religion and Humanitarian Responses.

61 Alastair Ager, interview, January 2017.

62 Ibid.

63 Enrique Garcia, interview, November 2016; Valentin, interview; Harris and Chadburn, interview.

64 Valentin, interview.

65 Harris and Chadburn, interview.

66 Kraft, interview; Dean Pallant, interview, December 2016; Harris and Chadburn, interview; Ager, remarks.

67 Ager, remarks.

$68 \mathrm{Kraft}$, interview. 
69 See, e.g., International Federation of the Red Cross and Red Crescent Societies (IFRC) and the International Committee of the Red Cross (ICRC), International Red Cross and Red Crescent Code of Conduct (Geneva: 1995), http://www.ifrc.org/Docs/idrl//259EN.pdf. See also David Chandler, "The Road to Military Humanitarianism: How the human rights NGOs shaped a new humanitarian agenda," Human Rights Quarterly 23, no.3 (2001): 678-700,

http://westminsterresearch.wmin.ac.uk/1724/1/Chandler_2001_final.pdf.

70 Juliano Fiori, interview, February 2017; Rudelmar Bueno de Faria, remarks, Harvard/Oxfam workshop, Cambridge, MA, January 2017; Anwar Khan, remarks, Harvard/Oxfam workshop, Cambridge, MA, January 2017. See also Humanitarian Policy Group, Time to let go, 46-53.

71 Oxfam, Oxfam's Role in Humanitarian Action, Oxfam Policy Compendium Note (June 2013), 3, https://www.oxfam.org/sites/www.oxfam.org/files/hpn-role-humanitarian-action-010613-en.pdf.

Although this did not come through in our interviews, adherence to the principle of neutrality by some FBOs is similarly affected by their strong sense of justice. Ferris, "Faith-Based and Secular Humanitarian Organizations," 319.

72 Core Humanitarian Standard,

http://www.corehumanitarianstandard.org/files/files/CHS\%20V3\%20FINAL(1).pdf.

73 Oxfam, "Oxfam's Role in Humanitarian Action."

74 Nightingale, interview (discussing the day-to-day challenges of implementing the principle, especially by groups who do not deal with the principles on a daily basis).

75 Fiori, interview; Tahir Zaman, remarks, Harvard/Oxfam workshop, Cambridge, MA, January 2017.

76 See, e.g., Schenkenberg, The Challenges of Localised Humanitarian Aid.

77 Vinya Ariyaratne, remarks, Harvard/Oxfam workshop, Cambridge, MA, January 2017.

78 Kathryn Kraft, "Faith and impartiality in humanitarian response: Lessons from Lebanese evangelical churches providing food aid," International Review of the Red Cross 97, no. 897-98 (June 2015): 395-421.

79 Russell Taylor, interview; Khan, interview; Poidatz, interview; Jordan, interview; Riera-Cézanne, interview ("This concern is born out of ignorance and fear"); Brinkmoeller, interview; Aminu-Kano, interview; Timmins, interview; Valentin, interview.

80 Khan, interview; Timmins, interview.

81 Kitchen, interview; Elizabeth Cano, interview, November 2016; Minkara, interview; Marshall, interview; Valentin, interview; Kassenberg, interview; Halleiso, remarks.

82 Nobuyuki, interview; Bueno de Faria, remarks (LFAs are first responders and do not discriminate in immediate response; problems arise later).

83 Timmins, interview; Mohamed-Saleem, interview; Khan, interview; Nightingale, interview; Kraft, interview. See also Humanitarian Policy Group, Time to let go, 52-53.

84 Timmins, interview.

85 Khan, interview (example of the Islamic teachings of mercy and compassion precluding partiality on religious grounds); Pallant, interview; Poidatz, interview; Nobuyuki, interview; Ruth Messinger, interview, December 2016

86 Mohamed-Saleem, interview; Nightingale, interview; Kraft, interview (suggesting that this translation of the principles is a role that intermediaries can play).

Mark Webster of ADRA shared an instructive example from work they are conducting on gender-based violence (GBV) in Papua New Guinea, where religion has played a "mixed role" regarding GBV. ADRA hired an external gender consultant to produce a set of guidelines on gender equality and GBV, but the draft was "very much a standard approach" to addressing the issues, and the religious leaders became defensive. As Mark said, however, "It didn't take much tweaking of the language in that document to shift it. There was no change in the intended outcomes, there was no lessening of the commitment to human rights and gender equality. And yet, by the use of the right kind of language and the right kind of religious language" they were able to get buy-in from the religious leaders to the extent that the leaders then worked with ADRA gender staff "and came back with a theology of gender equality that spoke to gender equality in the terms they understand and is a starting place in terms of a commitment to genuine deep-level change, as opposed to surface-level acceptance of gender equality norms." Webster, interview.

Nigel Timmins of Oxfam made the point that humanitarian organizations are largely founded on humanist principles, including human rights, that are focused on the role of the individual, while many religious traditions start from the perspective of the collective body, creating a perspective gap between these actors. Timmins, interview.

87 Arenas, interview; Garcia, interview; Jordan, interview; Blackham, interview.

88 Valentin, interview. According to Valentin, this negative perception stems from the behavior of other faith organizations, which engage in proselytizing "or an aggressive presentation of Christianity."

89 Jordan, interview. 
90 Elena Fiddian-Qasmiyeh, interview, December 2016; Riera-Cézanne, interview; Karam, interview; Nightingale, interview. See also Abdulaziz et al., Gender, Religion and Humanitarian Responses.

91 Riera-Cézanne, interview.

92 Alastair Ager, email message to author, March 2017. See also Abdulaziz et al., Gender, Religion and Humanitarian Responses, 12.

93 Katherine Marshall, remarks, Harvard/Oxfam workshop, Cambridge, MA, January 2017; Manal Omar, remarks, Harvard/Oxfam workshop, Cambridge, MA, January 2017; Khan, remarks.

94 Karam, interview.

95 Abdulaziz et al., Gender, Religion and Humanitarian Responses, 12.

96 Fiddian-Qasmiyeh, interview.

97 Abdulaziz et al., Gender, Religion and Humanitarian Responses, 12.

98 Brinkmoeller, interview; Marshall, interview.

99 Marshall, Global Institutions of Religion, 188-89. The other four are specific controls on financial flows to some religiously linked development and humanitarian institutions; diverse interpretations and reasons for accepting a human rights framework; knowledge gaps, weak networking, and preconceptions regarding the roles and work of faith institutions; and the need to define more clearly norms on religious freedom. See also Marshall, "Faith, Gender, and International Affairs," 184.

100 Marshall, Global Institutions of Religion, 186-87.

101 Ager, interview; Karam, interview. See also Abdulaziz et al., Gender, Religion and Humanitarian Responses.

102 Fiddian-Qasmiyeh, interview. See also Abdulaziz et al., Gender, Religion and Humanitarian Responses.

103 Karam, interview.

104 Mohamed-Saleem, interview; Jean Duff, remarks, Harvard/Oxfam workshop, Cambridge, MA, January 2017 (reporting frustration of LFAs); Karam, remarks.

105 Ager and Ager, Faith, Secularism, and Humanitarian Engagement. The Agers posit that humanitarian aid should move from marginalizing and instrumentalizing forms of engagement between INGOs and LFAs toward dialogical forms of engagement, where reasons and motivations for humanitarian work are recognized as part of the underlying relations of power, various religious and secular frameworks must be allowed to present issues and action items from within their respective framework, no one framework is allowed to dominate, and all coordinating actors spend time in dialogue working out various issues. Ibid.

Katherine Marshall likewise identifies the possibility of instrumentalized engagement in the sense that international organizations and donor agencies "are tempted to want to 'use' faith institutions to further already defined policies." Marshall, Global Institutions of Religion, 188-89.

106 Ager and Ager, Faith, Secularism, and Humanitarian Engagement, 12.

107 Moore, "Overcoming Religious Illiteracy," para. 2. See also Moore, "Definition of Religious Literacy." 108 Office of the UN High Commissioner for Refugees (UNHCR), Report on High Commissioner's Dialogue on Faith and Protection (UNHCR, 2012), http://www.unhcr.org/50aa5b879.pdf.

109 Father Thomas Smolich, interview, December 2016.

110 Webster, interview.

111 Arenas, interview.

112 Messinger, interview; Valentin, interview.

113 Webster, interview.

114 Webster, interview; Arenas, interview; Valentin, interview.

115 Arenas, interview.

116 Russell Taylor, interview; Valentin, interview (power analysis tools).

117 Poidatz, interview.

118 Tearfund, Reveal! Toolkit, http://tilz.tearfund.org/en/resources/reveal_toolkit/.

119 Bill Crooks and Jackie Mouradian, Disasters and the Local Church (Tearfund, 2011), http://tilz.tearfund.org/en/themes/disasters/disasters_and_the_local_church/.

120 Lucy V. Moore, Working in Conflict: A Faith Based Toolkit for Islamic Relief (Islamic Relief Worldwide, 2014), http://policy.islamic-relief.com/portfolio/working-in-conflict-a-faith-based-toolkit/.

121 Catholic Relief Services, Institute for Capacity Strengthening, http://www.crs.org/our-workoverseas/program-areas/partnership-and-capacity-strengthening.

122 Russell Taylor, interview. 
123 National Disaster Interfaiths Network and University of Southern California Center for Religion and Civic Culture, Religious Literacy Primer for Crises, Disasters, and Public Health Emergencies: A Field Guide Companion for Religious Literacy and Competency (2014); Federal Emergency Management Agency, "IS-505: Religious and Cultural Literacy and Competency in Disaster," https://training.fema.gov/is/courseoverview.aspx?code=IS-505.

124 This could be an issue of definitions.

125 Russell Taylor, interview; Olivia Wilkinson, interview, February 2016 (reporting findings from her research on the Typhoon Haiyan response).

126 See, e.g., Ramm, interview; Marshall, interview.

127 Valentin, interview.

128 Nightingale, interview; Bueno de Faria, remarks; Karam, remarks.

129 See, e.g., Smolich, interview.

130 Fiddian-Qasmiyeh, interview.

131 Riera-Cézanne, interview; Mahmood, interview; Marshall, remarks. The mapping conducted by the Berkley Center for Religion, Peace and World Affairs at Georgetown University is held out as an example of religious mapping. See https://berkleycenter.georgetown.edu/projects/global-mapping-of-faith-inspiredorganizations-and-development.

132 Duff, remarks (reporting that LFAs do not want to be mapped).

133 Karam, interview

134 Marshall, remarks; Duff, remarks.

135 Omar, remarks ("Secularism is a framework, just a different one, replacing religion with science"); Karam, remarks ("There is an ongoing secular bias; there is no such thing as secular neutrality"). See a discussion of these tensions in Judith Butler et al., The Power of Religion in the Public Sphere, ed. Eduardo Mendieta and Jonathan VanAntwerpen (New York: Columbia University Press, 2011). Charles Taylor, Jurgen Habermas, Judith Butler, and Cornel West all offer their perspective on the issue of religious language in secular contexts.

136 Abdulaziz et al., Gender, Religion and Humanitarian Responses.

137 Wilkinson, interview.

138 Cited in Marshall, Global Institutes of Religion, 188. The quote is commonly attributed to Maritain during discussions of the drafting committee of the 1948 UN International Declaration of Human Rights, although Maritain himself does not recall its source. See Maritain's "Introduction" to Human Rights: Comments and Interpretations - A symposium, ed. UNESCO (Paris: UNESCO, 1948), http://unesdoc.unesco.org/images/0015/001550/155042eb.pdf.

139 Sahar Fallal Ali, interview, December 2016; Riera-Cézanne, interview; Omar, remarks.

140 Karam, remarks; Bueno de Faria, remarks (likely gender, family); Sahar Ali, remarks, Harvard/Oxfam workshop, Cambridge, MA, January 2017 (gender, family law, inheritance laws)

141 Arenas, interview.

142 Ibid.

143 Timmins, interview.

144 Ager, interview. See also Abdulaziz et al., Gender, Religion and Humanitarian Responses.

145 Ager and Ager, Faith, Secularism, and Humanitarian Engagement, 78-99. Ager makes the point that in other contexts, INGOs are more likely to choose the more limited approach, whereas with LFAs, they tend to make the more drastic choice (e.g., over proselytism). Ager, interview.

146 Judy Beals, remarks, Harvard/Oxfam workshop, Cambridge, MA, January 2017.

147 Ager, interview.

148 It should be noted here, however, that most of our interviews were with humanitarian managers or directors in headquarters offices.

149 See discussion on page 16 about the tendency to hold local actors to a standard not required of international actors.

150 See discussion on page 17 about the assumption that secular actors are more progressive in terms of gender equality than faith-inspired ones. .

151 Stephen Kemmis and Robin McTaggart, "Participatory Action Research," in Handbook of Qualitative Research, ed. Norman K. Denzin and Yvonna S. Lincoln, 567-605 (Thousand Oaks, CA: Sage, 2005). $\mathrm{PAR}$ is a form of research intended to produce social change, increase the human flourishing of marginalized communities, and link education with social action. The key component of PAR is that it breaks down the power dynamics operative in traditional social science research in which the researcher analyzes an exploited community from a location of privilege. It is always action-oriented and self-critical. Here, the researchers would select a case study location(s) and engage in mutual mapping of participants 
and research questions/areas. However, the PAR research must be designed and conducted in such a way that the researchers merely contribute, but do not control, the study with respect to the means of analysis.

152 With respect to governmental and intergovernmental agencies, engaging religious actors for humanitarian and development work seems to be a newer, yet growing, phenomenon. Such efforts, however, remain defined primarily in terms of development rather than humanitarian aid specifically. However, that fact does not preclude those agencies from understanding humanitarian work under the umbrella of development work-as is the case for some NGOs.

Examples include the UN Interagency Task Force on Religion and Development; the World Band Group's Faith Initiative; USAID's Center for Faith-Based and Community Initiatives; the Values, Religion, and Development program at the German Federal Ministry for Economic Cooperation and Development (BMZ); and the International Partnership of Religion and Sustainable Development (PaRD), which gathers together bilateral donors and multilateral development agencies as members to partner with various civil society and non-governmental organizations.

153 Previously open only to UN agencies, the UN taskforce now welcomes INGOs as members.

154 Pallant, interview; Karam, interview.

155 The conference is being organized by a large number of FBOs and JLI. See http://pfaithdev.weebly.com/localizing-response-to-humanitarian-need.html.

156 UNHCR, Report on High Commissioner's Dialogue.

157 Pew Research Center, The Global Religious Landscape: A Report on the Size and Distribution of the World's Major Religious Groups as of 2010 (Washington, DC: Pew Research Center, 2012),

http://www.pewforum.org/2012/12/18/global-religious-landscape-exec/. 


\section{ACKNOWLEDGMENTS}

Tara Gingerich is Senior Humanitarian Researcher with Oxfam. Diane Moore is Director of the Religious Literacy Project at the Harvard Divinity School. Robert Brodrick is a PhD candidate at Boston College, and Carleigh Beriont is a PhD candidate at Harvard University.

The authors would like to thank Elena Fiddian-Qasmiyeh of University College London, Jean Duff of the Joint Learning Initiative on Faith \& Local Communities, and Alastair Ager of Queen Margaret University in Edinburgh and Columbia University for their contributions throughout the project.

They are also indebted to the people who participated in the interviews (listed in the Appendix) as well as the experts who attended the Harvard Divinity School workshop in January 2017 who shared their views on the research questions and provided feedback on the preliminary findings. Finally, they would like to thank the following reviewers who offered helpful feedback that improved the draft final report: Alastair Ager; Elena Fiddian-Qasmiyeh; Jean Duff; and Nahuel Arenas, Judy Beals, Marc Cohen, Alain Kergoat, Shannon Scribner, Lara Seigneur, Elizabeth Stevens, and Michelle Strucke of Oxfam.

This project would never have happened without the original idea of Judy Beals, the formative guidance of Carlos Mejia, and, above all, the support of Toby Volkman and the Henry Luce Foundation. 
This Research Report is being published to share research results, to contribute to public debate, and to invite feedback on humanitarian policy and practice. It does not necessarily reflect the policy positions of Oxfam and the Harvard Divinity School. The views expressed are those of the authors and not necessarily those of the publishers.

For more information, or to comment on this report, email Tara Gingerich at tara.gingerich@oxfam.org.

(C) Oxfam International and Harvard Divinity School March 2017

This publication is copyright but the text may be used free of charge for the purposes of advocacy, campaigning, education, and research, provided that the source is acknowledged in full. The copyright holder requests that all such use be registered with them for impact assessment purposes. For copying in any other circumstances, or for re-use in other publications, or for translation or adaptation, permission must be secured and a fee may be charged. Email policyandpractice@oxfam.org.uk.

The information in this publication is correct at the time of going to press.

Published by Oxfam GB for Oxfam International under ISBN 978-0-85598-942-2 in March 2017.

Oxfam GB, Oxfam House, John Smith Drive, Cowley, Oxford, OX4 2JY, UK.

DOI: $10.21201 / 2017.9422$

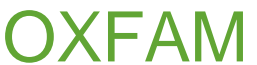

Oxfam is an international confederation of 20 organizations networked together in more than 90 countries, as part of a global movement for change, to build a future free from the injustice of poverty. Please write to any of the agencies for further information, or visit www.oxfam.org

Oxfam America (www.oxfamamerica.org)

Oxfam Australia (www.oxfam.org.au)

Oxfam-in-Belgium (www.oxfamsol.be)

Oxfam Brasil (www.oxfam.org.br)

Oxfam Canada (www.oxfam.ca)

Oxfam France (www.oxfamfrance.org)

Oxfam Germany (www.oxfam.de)

Oxfam GB (www.oxfam.org.uk)

Oxfam Hong Kong (www.oxfam.org.hk)

Oxfam IBIS (Denmark) (www.ibis-global.org)
Oxfam India (www.oxfamindia.org)

Oxfam Intermón (Spain) (www.intermonoxfam.org)

Oxfam Ireland (www.oxfamireland.org)

Oxfam Italy (www.oxfamitalia.org)

Oxfam Japan (www.oxfam.jp)

Oxfam Mexico (www.oxfammexico.org)

Oxfam New Zealand (www.oxfam.org.nz)

Oxfam Novib (Netherlands) (www.oxfamnovib.nl)

Oxfam Québec (www.oxfam.qc.ca)

Oxfam South Africa (www.oxfam.org.za)

\section{THE RELIGIOUS LITERACY PROJECT AT HARVARD DIVINITY SCHOOL}

The Religious Literacy Project at Harvard Divinity School is dedicated to enhancing and promoting the public understanding of religion. We provide resources and special training opportunities for educators, journalists, public health workers, foreign service officers, interfaith/multifaith groups, students, and others wishing to better understand the complex roles that religions play in contemporary global, national, and local contexts. For further information, visit http://rlp.hds.harvard.edu/. 